GEOLOGICAL SURVEY CIRCULAR 364

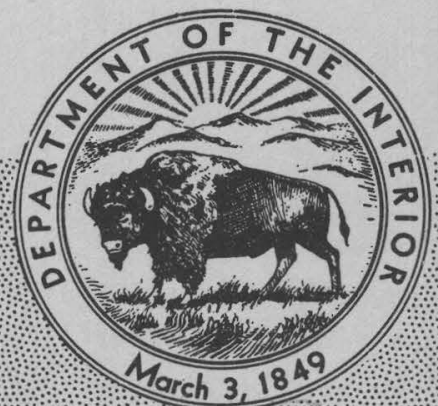

REPORTS AND MAPS OF

THE GEOLOGICAL SURVEY

RELEASED ONLY IN THE

OPEN FILES, 1954 

UNITED STATES DEPARTMENT OF THE INTERIOR

Douglas McKay, Secretary

GEOLOGICAL SURVEY

W. E. Wrather, Director

GEOLOGICAL SURVEY CIRCULAR 364

\section{REPORTS AND MAPS OF THE GEOLOGICAL SURVEY RELEASED ONLY IN THE OPEN FILES, 1954}

By Albert M. La Sala, Lois E. Randall, and Arthur Johnson 


$$
\text { - }
$$




\title{
REPORTS AND MAPS OF THE GEOLOGICAL SURVEY RELEASED ONLY IN THE OPEN FILES, 1954
}

\author{
By Albert M. La Sala, Lois E. Randall, and Arthur Johnson
}

\section{CONTENTS}

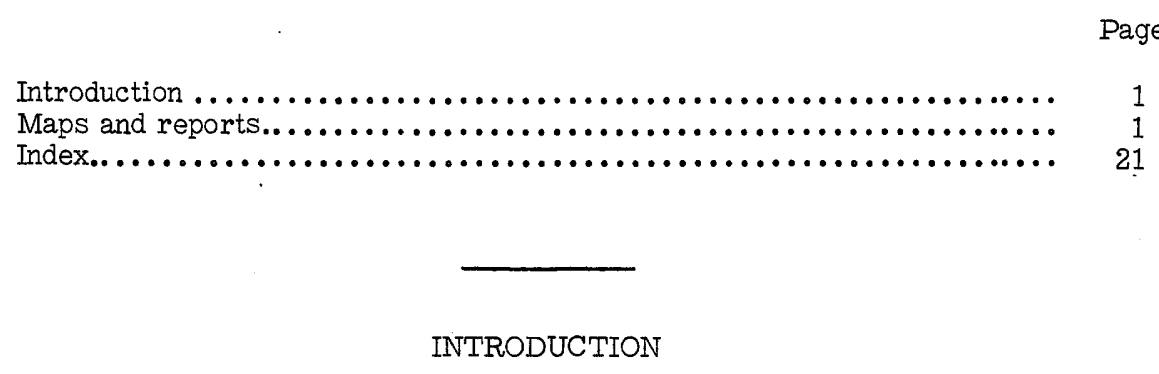

This circular contains a list of the maps and reports released by the Geological Survey in 1954 that are available only in open files. They may be consulted in the Geological Survey Library, in Washington, D. C., and at various field offices, the addresses of which are given immediately after the date of the report. They may also be read at the offices of various cooperating agencies, as indicated.

The following circulars list open-file reports and maps released during the years indicated: 56 (1946-47), 64 (1948), 149 (1949-50), 227 (1951), 263 (1952), and 337 (1953).

Most of the maps were duplicated by rapid and inexpensive processes, such as photostat, vandyke, or ozalid, but some were printed by photolithography. Most of the texts for the reports are typed copies (ribbon or carbon copy), but some have been mimeographed. A few of these reports and maps were made available in limited quantities for distribution, as indicated in the list, and these may be obtained as long as the supply lasts.
The report of the Conservation Division concerns the water power possibilities of the Seldovia River, Alaska.

The reports and maps of the Geologic Division contain results of work accomplished by Survey geologists in 36 States, Alaska, Puerto Rico, and Greenland. These maps and reports are released in preliminary form in order to make information immediately available to persons concerned with exploration for and production of minerals, fuels, and construction materials.

The reports of the Water Resources Division contain information on streamflow, ground water, quality of water, and related geology and hydrology in the United States and Alaska.

A general index follows, in which the reader is referred to a report by its serial number as listed in the following list of reports, which are arranged alphabetically by names of the authors.

\section{MAPS AND REPORTS}

1. Alaskan Geology Branch, Distillation analyses of natural gas for Gubik Test Well No. 1 and Umiat Test Well No. 8: 3 p. May 10, 1954. 2542 Dept. of Interior Bldg. , Washington, D. C. ; Office of the Inspector, Naval Petroleum Reserve No. 4, Fairbanks, Alaska.

2. Alaskan Geology Branch, Graphic and written logs, Gubik Test Well No. 1: 30 p., 1 pl. May 10, 1954. 2542 Dept. of Interior Bldg. , Washington, D. C. ; Office of the Inspector, Naval Petroleum Reserve No. 4, Fairbanks, Alaska.
3. Alaskan Geology Branch, Graphic and written logs, Gubik Test Well No. 2: 42 p., 1 pl. May 10, 1954. 2542 Dept. of Interior Bldg. , Washington, D. C. ; Office of the Inspector, Naval Petroleum Reserve No. 4, Fairbanks, Alaska.

4. Alaskan Geology Branch, Graphic and written logs, Umiat Test Well No. 8: 13 p., 1 pl. May 10, 1954. 2542 Dept. of Interior Bldg., Washington, D. C. ; Office of the Inspector, Naval Petroleum Reserve No. 4, Fairbanks, Alaska. 
5. Alaskan Geology Branch, Graphic and written logs, Umiat Test Well No. 11, 38 p., 1 pl. May 10, 1954. 2542 Dept. of Interior Bldg. , Washington, D. C.; Office of the Inspector, Naval Petroleum Reserve No. 4, Fairbanks, Alaska.

6. Alaskan Geology Branch, Index of publications or Alaskan geology: Card file of about 20, 000 cards. Oct. 14, 1954. Brooks Memorial Mines Bldg., College, Alaska; 117 Federal Bldg. , Juneau, Alaska; 210 E. F. Glover Bldg., Anchorage, Alaska; 4 Homeward Pl. , Menlo Park, Calif. ; 468 New Customhouse, Denver, Colo.; 529 post Office and Court House, Los Angeles, Calif.; Room 724, 630 Sansome St., San Francisco, Calif.

7. Alaskan Geology Branch, Preliminary photcgeologic maps of Naval Petroleum Reserve No. 4, and adjacent areas, Alaska; each map shows an area of approximately $2 \frac{1}{2}$ degrees long. and 45 minutes lat. at a scale of 1:250, 000; grid system is arbitrary: 12 maps. May 10, 1954. 2542 Dept. of Interior Bldg. , Washington, D. C. ; Office of the Inspector, Naval Petroleum Reserve No. 4, Fairbanks, Alaska.

8. Alaskan Geology Branch, Preliminary photogeologic maps of Naval Petroleum Reserve No. 4 and adjacent areas, Alaska; each map shows an area of 1 degree long. and $15 \mathrm{~min}$ utes lat. at a scale of 1:96,000; grid system is arbitrary: 104 maps. May 10, 1954. 2542 Dept. of Interior Bldg., Washington, D. C.; Office of the Inspector, Naval Petroleum Reserve No. 4, Fairbanks, Alaska.

9. Alaskan Geology Branch, Structure contour map of the Gubik anticlins based on seismograph data: 1 map. May 10, 1954. 2542 Dept. of Interior Bldg., Washington, D. C.; Office of the Inspector, Naval Petroleum Reserve No. 4, Fairbanks, Alaska.

10. Alaskan Geology Branch, Subsurface structure, Umiat Test Wells: 1 pl. May 10, 1954. 2542 Dept. of Interior Bldg., Washington, D. C.; Office of the Inspector, Naval Pe-troleum Reserve No. 4, Fairbanks, Alaska.

11. Anderson, I. E., Flood of August 1953 in the vicinity of Tylertown, Miss.: 15 p. , 8 figs. Sept. 15, 1954. 301 Century Bldg., Jackson, Miss.; 2238 General Services Administration Bldg., Washington, D. C.

12. Aronow, Saul, Problems in late Pleistocene and Recent history of the Devils Lake region, North Dakota: 123 p., 35 pls., 28 figs. December 27, 1954. University of North Dakota, Grand Forks, N. Dak. ; University of Wisconsin, Science Hall, Madison, Wis.; 1242-G General Services Administration Bldg. , Washington, D. C.
13. Babcock, H. M., and Norris, D. A., Ground water in the vicinity of Edgerton, Wyo.: $12 \mathrm{p}$., 1 fig. February 23, 1954. 2002 Capitol Ave., Room 300, Cheyenne, Wyo.; 510 Rudge-Guenzel Bldg. , Lincoln, Nebr.; 1242-GGeneral Services Administration Bldg. , Washington, D. C.

14. Bailey, R. A., Fusion of arkosic sand by intrusive andesite: 87 p., 3 pls., 28 figs. July 27, 1954.

15. Bass, N. W., Geology and mineral fuels of the Mount Harris, Pilot Knob, Elkhead Creek, and Daton Peak quadrangles, Routt and Moffat Counties, Colo.: 82 p., 4 maps, 6 figs., 3 pls., 11 tables. Mar. 25, 1954. 4240 General Services Administration Bldg. , Washington, D. C. ; 468 New Customhouse, Denver, Colo.

16. Bennett, H. S., Photogeologic map, Navajo Mountain 5 quadrangle, Kane and San Juan Counties, Utah: 1 map. Mar. 12, 1954. 504 Federal Bldg., Salt Lake City, Utah; 4068 New Customhouse, Denver, Colo.

17. Bennett, H. S., Photogeologic map, Navajo Mountain 12 quadrangle, Kane and San Juan Counties, Utah: 1 map. Apr. 26, 1954. 504 Federal Bldg., Salt Lake City, Utah; 468 New Customhouse, Denver, Colo.; Grand Junction, Colo.; Bureau of Indian Affairs, Window Rock, Ariz.

18. Bennett, H. S., Photogeologic map, Tidwell 6 quadrangle, Emery County, Utah: 1 map. July 27, 1954. 504 Federal Bldg., Salt Lake City, Utah; 468 New Customhouse, Denver, Colo.; Grand Junction, Colo.

19. Bergquist, H. R., Micropaleontological studies in 1952: 10 p., 2 figs. May 10, 1954. 2542 Dept. of Interior Bldg., Washington, D. C.; Office of the Inspector, Naval Petroleum Reserve No. 4, Fairbanks, Alaska.

20. Bergquist, H. R., Paleontologic correlations in northern part of Naval Petroleum Reserve No. 4, 1949: 9 p., 2 pls. May 10, 1954. 2542 Dept. of Interior Bldg., Washington, D. C.; Office of the Inspector, Naval Petroleum Reserve No. 4, Fairbanks, Alaska.

21. Bergquist, H. R., Recent developments in paleontologic studies, 1951: 11 p., 1 fig. May 10, 1954. 2542 Dept. of Interior Bldg. , Washington, D. C. ; Office of the Inspector, Naval Petroleum Reserve No. 4, Fairbanks, Alaska.

22. Bergquist, H. R., Summary of paleontology of wells drilled since April 1949, 1950: 9 p. , 1 fig. May 10, 1954. 2542 Dept. of Interior Bldg., Washington, D. C. ; Office of the Inspector, Naval Petroleum Reserve No. 4, Fairbanks, Alaska. 
23. Blankenship, R. R., Heavy minerals suites in the unconsolidated sands of Paleocene age and younger in western Tennessee: $23 \mathrm{p}$. March 31, 1954. Memphis General Depot, U. S. Army, Memphis, Tenn, ; 1242-G General Services Administration Bldg. , Washington, D. C.

24. Bolon, H. C., Low-water study, Spring River basin, Mo.: 7 p., 1 fig., 1 map. March 31, 1954. 211 Ramsay Bldg., Rolla, Mo.; 2238 General Services Administration Bldg. Washington, D. C.

25. Bowsher, A. L., and Dutro, J. T., Jr., Preliminary report on the Mississippian rocks of the Kanayut, Nanushuk, and Itillik Lakes area, Alaska, 1949: 41 p., 1 fig., 6 pls. May 10, 1954. 2542 Dept. of Interior Bldg. , Washington, D. C.; Office of the Inspector, Naval Petroleum Reserve No. 4, Fairbanks, Alaska.

26. Bowyer, Ben, Rainey, H. C., and others, Geologic map of the Wallace and vicinity quadrangle, Shoshone County, Idaho: 1 map. July 14, 1954. South 157 Howard St., Spokane, Wash.; 504 Federa Bldg., Salt Lake City, Utah; Idaho Bureau of Mines and Geology, Moscow, Idaho.

27. Breeding, S. D., Floods in Devils and Pecos River basins of Texas, June 27-28, 1954miscellaneous data: $8 \mathrm{p}$. November 10, 1954. 302 West 15th Street, Austin, Tex.; 300 West Vickery, Fort Worth, Tex. ; 1013 Federal Bldg. , Houston, Tex.; 1602 West Beauregard St., San Angelo, Tex.; 308 Federal Bldg., Wichita Falls, Tex.; 2238 General Services Administration Bldg., Washington, D. C.

28. Britt, S. H., Translation of "Contribution to the study of the physico-chemical structure of clays, " by Remy Hebert. Published in French as "Contribution a l'étude de la structure physico-chimique des argiles" in Annales des Mines, no. 6, p. 3-48, Paris, 1950. Aug. 30, 1954. Bldg. 25, Denver Federal Center, Denver, Colo.

29. Britt, S. H., Translation 33. "The Landslides of Sainte-Adresse Cliff, " by M. M. Buisson, Ann. inst. tech. batiment et trav. pub., 5me ann., no. 59, p. 1131-1146, 12 figs., discussion.: 37 p., 12 figs. July 14, 1954. 1232 General Services Administration Bldg. , Washington, D. C. ; 468 New Customhouse, Denver, Colo.

30. Britt, S. H., Translation of "Measurement of earth pressure in the iron-ore mines of eastern France, " by M. E. Tincelin. Published in French as "Mesures des pressions de ter rains dans les mines de fer de l'Est" in Annales de 1'Institut Techniques du Bâtiment et des Travaux Publics, série: Sols et fondations $(x)$, no. 58, p. 972-990, 22 figs. , 2 appendices, 1952. Nov. 8, 1954. 468 New Customhouse, Denver, Colo.
31. Britt, S. H., Translation of Measurement of earth pressures by means of the flat jack test, by P. Habib and R. Marchand. Published in French as Mesures des pressions de terrains par l'essai de vérin plat, in Annales de l'Institut technique du bâtiment et des travaux publics, sér.: Sols et fondations (x), no. 58, p. 966-971, 5 figs. , 1952. Nov. 8, 1954. 468 New Customhouse, Denver, Colo.

32. Britt, S. H., Translation of Observation of a "front" of regional metamorphism, by Rene Perrin and Marcel Roubault. Published in French as Observation d'un "front" de métamorphisme regional, in Bulletin de la Société Géologique de France, ser. 5, v. 11 p. 183-193, 5 figs., 2 pls., 1941. Nov. 8 , 1954. 468 New Customhouse, Denver, Colo.

33. Britt, S. H., Translation of "Water, frost, and frost resistance of natural and artificial building stones, " by H. Breyer. Published in German as "Wasser, Frost, und Frostbeständigkeit bei naturlichen und künstlichen Bausteinen" in Tonindustrie Zeitung, Band 75, Heft 9/10, p. 135-136, 1951, Wilhelmshafen. Nov. 8, 1954. 468 New Customhouse, Denver, Colo.

34. Bromfield, C. S., and Sirride, A. F., Mineral resources of the San Carlos Indian Reservation: 113 p., 13 illus. Nov. 8, 1954. Globe, Ariz. ; Arizona Bureau of Mines, Tucson, Ariz.

35. Brosge, W. P., Dutro, J. T., Jr., Mangus, M. D., and Reiser, H. N., Preliminary report on the stratigraphy and structure of some selected localities in the Eastern Brooks Range, Alaska, 1952: 28 p., 6 pls. May 10, 1954. 2542 Dept. of Interior Bldg., Washington, D. C. Office of the Inspector, Naval Petroleum Reserve No. 4, Fairbanks, Alaska.

36. Brosge, W. P., and Kover, A. N., Stratigraphy and structure of the Titaluk anticline in the vicinity of Maybe Creek, Alaska, 1950: 9 p., 1 fig., 2 pls. May 10, 1954. 2542 Dept. of Interior Bldg., Washington, D. C. ; Office of the Inspector, Naval Petroleum Reserve No. 4, Fairbanks, Alaska.

37. Brosge, W. P., and Reiser, H. N., Progress report on photogeology structure studies in the Chandler River area, Alaska, 1952: 3 p., 1 pl. May 10, 1954. 2542 Dept. of Interior Bldg., Washington, D. C.; Office of the Inspector, Naval Petroleum Reserve No. 4, Fairbanks, Alaska.

38. Brosge, W. P., and Reiser, H. N., Selected sections of the Lisburne limestone, Brooks Range, Alaska, 1951: 24 p., 9 figs., 6 pls. May 10, 1954. 2542 Dept. of Interior Bldg., Washington, D. C.; Office of the Inspector, Naval Petroleum Reserve No, 4. Fairbanks, Alaska. 
39. Brown, Eugene, The quality of surface waters of Lee County, Fla.: 8 p., 3 figs., 1 table. Oct. 17, 1954. P. O. Box 607, Bldg. 211, Camp Roosevelt, Ocala, Fla.

40. Brown, Eugene, Water supply in Florida: 15 p. 3 figs. Dec. 2, 1954. P. O. Box 607, Bldg. 211, Camp Roosevelt, Ocala, Fla.

41. Buddington, A. F., Two geologic maps: Part of the Big Moose quadrangle, N. $Y_{1}$, and part of the Port Leyden quadrangle, N. Y.: 2 maps. July 14, 1954. Beltsville, Md.; 468 New Customhouse, Denver, Colo.; Office of the State Geologist, State Geological and Natural History Surveys, University of the State of New York, Albany, N. Y.; Gouverneur Reading Room Association, Gouverneur, N. Y.

42. Buddington, A. F., and Leonard, B. F., Geologic maps of part of St. Lawrence County, N. Y.: 9 maps. Apr. 20, 1954. Beltsville, Md.; 468 New Customhouse, Denver, Colo.; Office of the State Geologist, State Geolorical and Natural History Surveys, University of the State of New York, Albany, N. Y.; Gouverneur Reading Room Association, Gouverneur, N. Y.

43. Burnham, W. L., Data on water wells in Borrego, Ocotillo, San Felipe, and Vallecito Valley areas, eastern San Diego County, Calif.: 60 p., 1 pl. December 27, 1954. 2520 Marconi Ave., Sacramento, Calif.; 1242-G General Services Administration Bldg., Washington, D. C.

44. Cardwell, G. T., Estimates of permeability of water-bearing deposits in Bayward portions of Napa, Sonoma, and Petaluma Valleys, Calif.: 5 p. December 27, 1954. 2520 Marconi Ave., Sacramento, Calif.; 1242-G General Services Administration Bldg., Washington, D. C.

45. Carswell, L. D., Swanson, R. W. , Sheldon, R. P., and Cheney, T. M., Stratigraphic sections of the Phosphoria formation measured and sampled in 1953: 15 p. July 14, 1954. South 157 Howard St., Spokane, Wash.; Menlo Park, Calif.; Montpelier, Idaho; 504 Federal Bldg., Salt Lake City, Utah; Idaho Bureau of Mines and Geology, Moscow, Idaho; Montana Bureau of Mines and Geology, Butte, Mont.; University of Utah, Salt Lake City, Utah; Wyoming Geological Survey, Laramie, Wyo.

46. Cass, J. T., Photogeologic map, Desert Lake 9 quadrangle, Emery County, Utah: 1 map. Apr. 26, 1954. 504 Federal Bldg., Salt Lake City, Utah; 468 New Customhouse, Denver, Colo.; Grand Junction, Colo.

47. Cathcart, J. B., Drilling of airborne radioactivity anomalies in Florida, Georgia, and South Carolina-1954: 10 p., 1 sketch map. Sept. 30, 1954. Plant City, Fla.
48. Chapman, R. M., and Eberlein, G. D., Stratigraphy and structure of upper Oolamnagavik, Kurupa, and Etivluk Rivers area, Alaska, 1951: 22 p., 6 figs., 9 pls. May 10, 1954. 2542 Dept. of Interior Bldg., Washington, D. C.; Office of the Inspector, Naval Petroleum Reserve No. 4, Fairbanks, Alaska.

49. Chapman, R. M., and Sable, E. G., Stratigraphy and structure of the Kokilik and Kukpowruk Rivers area, Alaska, 1950: 71 p., 4 figs., 3 pls. May 10, 1954. 2542 Dept. of Interior Bldg., Washington, D. C. ; Office of the Inspector, Naval Petroleum Reserve No. 4, Fairbanks, Alaska.

50. Chapman, R. M., and Thurrel, R. F., Jr., Stratigraphy and structure of the area of the Kurupa, Oolamnagavik, Killik, and Colville Rivers: 12 p., 3 pls. May 10, 1954. 2542 Dept. of Interior Bldg., Washington, D. C.; Office of the Inspector, Naval Petroleum Reserve No. 4, Fairbanks, Alaska.

51. Coates, D. R., Memorandum on ground-water investigations in the Sells area, Papago Indian Reservation, Pima County, Ariz.: 8 p., 1 pl. December 27, 1954. 18 East McCormick St., Tucson, Ariz.; 1242-G General Services Administration Bldg., Washington, D. C.

52. Coates, D. R., and Halpenny, L. C., Groundwater field trip, Tucson to Nogales, Ariz.: 22 p., 2 pls. , 6 figs. July 23, 1954. 18 Eas.t McCormick St., Tucson, Ariz.; 1242-GGeneral Services Administration Bldg., Washington, D. C.

53. Colby, B. C., Manson, P. W., and Schwantes, A. J., A study of accredited agriculture engineering curriculums: 7 p., 2 figs. June 1954. University of Minnesota Hydraulics Laboratory, Hennepin Island and Third Ave., S. E., Minneapolis, Minn.; 1242-L General Services Administration Bldg., Washington, D. C.

54. Colton, R. B., Geology of the Chelsea and Poplar quadrangles, Mont.: 1 map. Apr. 20, 1954. 315 Federal Bldg., Billings, Mont.; Office of the Regional Geologist, Conservation Division, 417 Electric Bldg., Great Falls, Mont.; 468 New Customhouse, Denver, Colo.; Office of the Director, State Bureau of Mines and Geology, Butte, Mont.

55. Condon, W. H., Photogeologic map, Desert Lake 7 quadrangle, Emery County, Utah: 1 map. Sept. 30, 1954. 504 Federal Bldg., Salt Lake City, Utah; 468 New Customhouse, Denver, Colo.; Grand Junction, Colo.

56. Condon, W. H., Photogeologic map, Desert Lake 10 quadrangle, Emery County, Utah: 1 map. Sept. 30, 1954. 504 Federal Bldg., Salt Lake City, Utah; 468 New Customhouse, Denver, Colo.; Grand Junction, Colo. 
57. Condon, W. H., Photogeologic map, Orange Cliffs 9 quadrangle, Garfield and Wayne Counties, Utah: 1 map. Apr. 26, 1954. 504 Federal Bldg., Salt Lake City, Utah; 468 New Customhouse, Denver, Colo.; Grand Junction, Colo.

58. Condon, W. H. , Structural patterns of Seward B 2 quadrangle, Alaska: 1 map. Oct. 29, 1954. 2650 Dept. of Interior Bldg., Washington, D. C.

59. Craig, F. C., Kelley, W. E., and Olmsted, F. H., Interchange of surface and ground water along tributary streams in the Sacramento Valley, Calif., July 1952 to December 1953: 63 p., 12 illus. September 15, 1954. 541 Federal Office Bldg. , San Francisco, Calif.; 2520 Marconi Ave., Sacramento, Calif. ; 2238 General Services Administration Bldg., Washington, D. C.

60. Crosthwaite, E: G., Ground-water development and problems in Idaho: 17 p. June 17, 1954. 720 Idaho St., Boise, Idaho; 1242-G General Services Administration Bldg., Washington, D. C.

61. Cushman, R. V., Memorandum on ground-water conditions in Haddam, Conn.: 7 p., 1 pl. March 31, 1954. Post Office Bldg., Room 1, Middletown, Conn.; 230 Old Country Road, Mineola, L. I. , N. Y.; 1242-G General Services Administration Bldg., Washington, D. C.

62. Cushman, R. V., Progress report of cooperative ground-water investigations for Connecticut for the year ended June 30, 1954: $1 \mathrm{p}$. November 10, 1954. 230 Old Colony Road, Mineola, L. I., N. Y.; Post Office Bldg., Room 1, Middletown, Conn. ; 1242-G General Services Administration Bldg., Washington, D. C.

63. Dana, S. W., Calculated gravity anomaly produced by possible fault under Line 27-48, 1949: 2 p., 2 figs. May 10, 1954. 2542 Dept. of Interior Bldg., Washington, D. C.; Office of the Inspector, Naval Petroleum Reserve No. 4, Fairbanks, Alaska.

64. Dana, S. W., Correlation of geophysical and geological data from Naval Petroleum Reserve No. 4, 1948: 11 p., 2 figs., 2 pls. May 10, 1954. 2542 Dept. of Interior Bldg., Washington, D. C. ; Office of the Inspector, Naval Petroleum Reserve No. 4, Fairbanks, Alaska.

65. Dana, S. W., Possible seismic evidence for the base of the Tertiary in the eastern part of Naval Petroleum Reserve No. 4, 1949: 3 p., 7 figs. May 10, 1954. 2542 Dept. of Interior Bldg. , Washington, D. C. ; Office of th.e Inspector, Naval Petroleum Reserve No. 4, Fairbanks, Alaska.

66. Davis, G. H., and others., Table showing estjmated ground-water storage capacity of the San Joaquin Valley, Calif., and map showing ground-water storage units in the San Joaquin Valley: June 17, 1954. 2520 Marconi Ave., Sacramento, Calif.; 1242-G General Services Administration Bldg., Washington, D. C.
67. Dempsey, W. J., Total intensity aeromagnetic map of part of Grant County, N. Mex.: 1 map. Mar. 12, 1954. 468 New Customhouse, Denver, Colo.; 504 Federal Bldg., Salt Lake City, Utar: State Geologist, New Mexico Bureau of Mines and Mineral Resources, Socorro, N. Mex.

68. Derragon, E. , The results of a pumping test at Foley, Taylor County, Fla.: 34 p., 8 figs. February 23, 1954. New Dining Hall Bldg., Florida State University, Tallahassee, Fla.; 1242-G General Services Administration Bldg. , Washington, D. C.

69. Detterman, R. L., and Bickel, R. S., Prelimine.r report on the stratigraphy and structure of the Grandstand and Hawk anticlines and vicinity, 1952: 19 p., 5 pls. May 10, 1954. 2542 Dept. of Interior Bldg., Washington, D. C.; Office of the Inspector, Naval Petroleum Reserve No. 4, Fairbanks, Alaska.

70. Detterman, R. I., and Bickel, R. S., Stratigraphy and structure of part of Big Bend anticline, Alaska, 1953: 4 p., 1 pl. May 10, 1954. 2542 Dept. of Interior Bldg., Washington, D. C.; Office of the Inspector, Naval Petroleum Reserve No. 4, Fairbanks, Alaska.

71. Detterman, R. L., Webber, E. J., and Mathewson, D. E., Stratigraphy and structure of the area of the Colville River between Ninuluk Creek and Umiat Mountain, Alaska, 1948: 9 p., 3 pl. May 10, 1954. 2542 Dept. of Interior Bldg., Washington, D. C.; Office of the Inspector, Naval Petroleum Reserve No. 4, Fairbanks, Alaska.

72. Dutro, J. T.,Jr., Lachenbruch, M. C., and Lachenbruch, A. H. , Stratigraphy and structure of the western Noatak district, Alaska, 1951: 22 p. , 4 figs., , 2 pls. May 10, 1954. 2542 Dept. of. Interior Bldg., Washington, D. C.; Office of the Inspector, Naval Petroleum Reserve No. 4, Fairbanks, Alaska.

73. Dutton, C. E., Iron deposits of North America, Cuba, and Puerto Rico: 44 p., 8 pls., 4 tables. Apr. 20, 1954.

74. Eberlein, G. D., Chapman, R. M., and Reynolds, C. D., The stratigraphy and structure. of the Aupuk anticline, 1950: 13 p. , 3 pls. May 10, 1954. 2542 Dept. of Interior Bldg., Washington, D. C.; Office of the Inspector, Naval Petroleum Reserve No. 4, Fairbanks, Alaska.

75. Ecksteir, W. F.., Phctogeologic map, Moab 13 quadrangle, Grand and Emery Counties, Utah: 1 map. Apr. 26, 1954. 504 Federal Bldg. , Salt Lake City, Utah; 468 New Customhouse, Denver, Colo.; Grand Junction, Colo.

76. Eschman, D. F., Geologic reconnaissance along the proposed location for the Orange-Athol Bypass between Ward Hill Road, Phillipston, and the Orange, Mass., town line: 5 p., 1 pl. Apr. 26, 1954. Room 1, 270 Dartmouth St. , Boston, Mass.; Massachusetts Department of Puiblic Roads, 100 Nashua St. , Boston, Mass. 
77. Fader, S. W., An analysis of water-level contour maps of southwestern Louisiana, 1952 and 1953: 6 p., 4 pls., 1 fig. June 17, 1954. 16 Geology Bldg. , University of Louisiana, Baton Rouge, La.; 1242-G General Services Administration Bldg., Washington, D. C.

78. Fader, S. W., and Harder, A. H., Preliminary memorandum on the effects of the proposed Cocodrie and Longleaf reservoirs and the Vermillion River on ground-water recharge in southwestern Louisiana: 11 p., 2 figs. May 10, 1954. 16 Geology Bldg., University of Louisiana, Baton Rouge, La.; Louisiana Geological Survey, Baton Rouge, La.; 1242-G General Services Administration Bldg., Washington, D. C.

79. Fellows, R. E., Significance and preliminary results of heavy mineral studies in northern Alaska, 1946: 4 p., 3 figs. 2542 Dept. of Interior Bldg., Washington, D. C.; Office of the Inspector, Naval Petroleum Reserve No. 4, Fairbanks, Alaska.

80. Ferris, J. G., and Knowles, D. B., The "slug test" for estimating transmissibility: $4 \mathrm{p}$., 2 figs. July 23, 1954. 1242-G General Services Administration Bldg. , Washington, D. C.

81. Feth, J. H., Geologic and ground-water reconnaissance of the Patagonic area, Ariz.: 12 p., 1 fig. February 23, 1954. 18 East McCormick St., Tucson, Ariz.; 1242-G General Services Administration Bldg., Washington, D. C.

82. Finch, W. I., Geology of the Shinarump No. 1 uranium mine, Seven Mile Canyon area, Grand County, Utah: 18 p., 8 figs. , 2 tables. Jan. 11, 1954. 504 Federal Bldg., Salt Lake City, Utah; Grand Junction, Colo.

83. Fischer, W. A., The Carbon Creek and Awuna anticlines, 1949: 5 p., 1 pl. May 10, 1954. 2542 Dept. of Interior Bldg., Washington, D. C. ; Office of the Inspector, Naval Petroleum Reserve No. 4, Fairbanks, Alaska.

84. Fischer, W. A., The Driftwood anticline, 1949: 4 p. , 3 pls. May 10, 1954. 2542 Dept. of Interior Bldg., Washington, D. C.; Office of the Inspector, Naval Petroleum Reserve No. 4, Fairbanks, Alaska.

85. Fischer, W. A., Interpretations from aerial photographs of geologic structures of the central Colville River area, Alaska, 1949: 11 p., 1 pl. May 10, 1954. 2542 Dept. of Interior Bldg., Washington, D. C.; Office of the Inspector, Naval Petroleum Reserve No. 4, Fairbanks, Alaska.

86. Fischer, W. A., Photogeologic mapping in northern Alaska, 1950: 11 p. May 10, 1954. 2542 Dept. of Interior Bldg. , Washington, D. C. ; Office of the Inspector, Naval Petroleum Reserve No. 4, Fairbanks, Alaska.
87. Fischer, W. A., Review and photogeologic evaluation of some selected anticlines in the Maybe Creek area, 1950: 6 p., 1 fig., 2 pls. May 10, 1954. 2542 Dept. of Interior Bldg., Washington, D. C. ; Office of the Inspector, Naval Petroleum Reserve No. 4, Fairbanks, Alaska.

88. Fischer, W. A., Review and photogeologic evaluation of selected anticlines, 1951: $21 \mathrm{p}$. 5 pls. May 10, 1954. 2542 Dept. of Interior Bldg., Washington, D. C.; Office of the Inspector, Naval Petroleum Reserve No. 4, Fairbanks, Alaska.

89. Fischer, W. A., and Kover, A. N., Review of the stratigraphy and structure of the Gubik anticline, 1950: $3 \mathrm{p} ., 1 \mathrm{pl}$. May 10, 1954. 2542 Dept. of Interior Bldg., Washington, D. C.; Office of the Inspector, Naval Petroleum Reserve No. 4., Fairbanks, Alaska.

90. Flint, A. E., and Brown, C. E., Geologic map and recent drilling data of the Durango area, Dubuque County, Iowa: 21 p., 2 figs. Jan. 11, 1954. 213 Science Hall, University of Wisconsin, Madison, Wis.; 108 Wisconsin Institute of Technology, Platteville, Wis.; Iowa Geological Survey, Geology Annex, Iowa City, Iowa.

91. Foster, M. D., The relation between composition and swelling in clays: 28 p., 10 figs. Sept. 30, 1954. 724 Appraisers Bldg., San Francisco, Calif.

92. Freeman, V. L., Geology of parts of the Johnny Gulch quadrangle, Mont.: 57 p., 3 figs., 9 pls. Nov. 8, 1954. South 157 Howard St., Spokane, Wash.; Montana Bureau of Mines and Geology, Butte, Mont.

93. Garrett, A. A., and Dutcher, L. C., Tables of basic data to accompany report on geologic and hydrologic features of the San Bernardino area, Calif., with special reference to underflow across the San Jacinto fault: 170 p., 2 pls. September 15, 1954. 221 Redondo Ave., Long Beach, Calif.; 2520 Marconi Ave., Sacramento, Calif.; 1242-G General Services Administration Bldg., Washington, D. C.

94. Gates, G. O., Evaluation of anticlinal structures as related to petroleum exploration in northern Alaska, 1948: 13 p. May 10, 1954. 2542 Dept. of Interior Bldg., Washington, D. C.; Office of the Inspector, Naval Petroleum Reserve No. 4, Fairbanks, Alaska.

95. Geophysics branch, Geophysical maps of Salt Lake Valley, Utah: 3 maps. July 16, 1954. 468 New Customhouse, Denver, Colo.; 504 Federal Bldg., Salt Lake City, Utah. 
96. Geophysics branch, Preliminary total-intensity aeromagnetic maps of parts of Franklin and Somerset Counties, Maine: 3 maps. July 15, 1954. Room 1, 270 Dartmouth St., Boston, Mass.; Maine Development Commission, State House, Augusta, Maine; Office of the State Geologist, University of Maine, Orono, Maine.

97. Geophysics branch, Preliminary total-intensity aeromagnetic map of southern Prince of Wales Island, Alaska: 1 map. June 23, 1954. Federal Bldg., Juneau, Alaska; 210 E. F. Glover Bldg., Anchorage, Alaska; Brooks Memorial Mines Bldg., College, Alaska; 529 Post Office and Court House Bldg., Los Angeles, Calif.; 4 Homeward Pl. , Menlo Park, Calif.; 468 New Customhouse, Denver, Colo.

98. Geraghty, J. J., Supplementary data on water levels and chloride concentrations at outpost observation wells in southern Nassau County, Long Island, N. Y.: December 27, 1954. 230 Old Country Road, Mineola, L. I. , N. Y.; 1242-G General Services Administration Bldg. , Washington, D. C.

99. Gillerman, Elliot, Swinney, C. M., Whitebread, D. H., Crowley, R. J., and Kleinhampl, F. G. Geologic map of the central part of the White Signal district, Grant County, N. Mex.: 1 map. Apr. 26, 1954. 468 New Customhouse, Denver, Colo.; Bureau of Mines and Mineral Resources, New Mexico Institute of Mining and Technology, Socorro, N. Mex.

100. Gillerman, Elliot, and Whitebread, D. H., Geologic map of the Black Hawk mining district, Grant County, N. Mex. : 1 map. July 14, 1954. 468 New Customhouse, Denver, Colo.; 504 Federal Bldg., Salt Lake City, Utah; 724 Appraiser's Bldg. , San Francisco, Calif.; 807 Post Office and Courthouse, Los Angeles, Calif.; New Mexico Bureau of Mines and Mineral Resources, Socorro, N. Mex.; Arizona Bureau of Mines, University of Arizona, Tucson, Ariz.

101. Gould, H. R., Lake Mead sedimentation: 333 p., 55 figs. Feb. 1b̆, 1954. 468 New Customhouse, Denver, Colo.; University of Southern California, Los Angeles, Calif.

102. Granger, A. E., and others, Reconnaissance geologic map of Elko County, Nev.: 1 map. June 1, 1954. 724 Appraisers Bldg., San Francisco, Calif. ; 529 Post Office and Court House, Los Angeles, Calif.; 504 Federal Bldg. , Salt Lake City, Utah; Nevada Bureau of Mines, Room 201, Mackay School of Mines Bldg., University of Nevada, Reno, Nev.

103. Grantz, Arthur, Magnetite deposits at Tuxedni Bay, Alaska: 17 p., 1 fig., 3 pls. July 27, 1954. Brooks Memorial Mines Bldg., University of Alaska, College, Alaska; 210 E. F. Glover Bldg., Anchorage, Alaska; Territorial Department of Mines, Juneau, Alaska; 724 Appraisers Bldg., San Francisco, Calif.
104. Gryc, George, Petrographic study of some Lisburne limestone samples, 1948: 6 p. , 1 fig. May 10, 1954. 2542 Dept. of Interior Bldg., Washington, D. C. ; Office of the Inspector, Naval Petroleum Reserve No. 4, Fairbanks, Alaska.

105. Gryc, George, Progress report on taxonomic and stratigraphic study of macrofossils, 1947: 10 p., 1 fig. May 10, 1954. 2542 Dept. of Interior Bldg., Washington, D. C.; Office of the Inspector, Naval Petroleum Reşerve No. 4, Fairbanks, Alaska.

106. Gryc, George, Reconnaissance survey of the Lower Kuparuk River area, 1946: 1 p. May 10, 1954. 2542 Dept. of Interior Bldg., Washington, D. C.; Office of the Inspector, Naval Petroleum Reserve No. 4, Fairbanks, Alaska.

107. Gryc, George, and Jensen, Comdr. R. C., Results of petroleum exploration in Naval Petroleum Reserve No. 4 and adjacent areas, Alaska: 8 p. Mar. 12, 1954. 4224 General Services Administration Bldg., Washington, D. C. ; 4 Homeward Pl., Menlo Park, Calif.; Brooks Memorial Bldg., University of Alaska, College, Alaska; Federal Bldg., Juneau, Alaska; 210 E. F. Glover Bldg., Anchorage, Alaska.

108. Gryc, George, and Lathram, E. H., Preliminary report on the geology of the Sagavanirtok River area, 1946: 5 p. May 10, 1954. 2542 Dept. of Interior Bldg., Washington, D. C.; Office of the Inspector, Naval Petroleum Reserve No. 4, Fairbanks, Alaska.

108. Gryc, George, and Lathram, E. H., Stratigraphy and structure of the area south of the Colville River between the mouths of Ninuluk and Prince Creeks, 1946: 4 p., 2 pls. 2542 Dept. of Interior Bldg., Washington, D. C.; Office of the Inspector, Naval Petroleum Reserve No. 4 Fairbanks, Alaska.

110. Gryc, George, and Mangus, Marvin, D., Preliminary report on the stratigraphy and structure of the area of the Shadiovik and Canning Rivers, Alaska, 1947: 7 p., 1 pl. May 10, 1954. 2542 Dept. of Interior Bldg., Washington, D. C. Office of the Inspector, Naval Petroleum Reserve No. 4, Fairbanks, Alaska.

111. Hackman, R. J., Photogeologic map, Carlisle 14 quadrangle, San Juan County, Utah: 1 map. Sept. 30, 1954. 504 Federal Bldg., Salt Lake City, Utah; 468 New Customhouse, Denver, Colo.; Grand Junction, Colo.

112. Hackmain, R. J., Photogeologic map, Carlisle 15 quadrangle, San Juan County, Utah: 1 map. Feb. 15, 1954. 468 New Customhouse, Denver, Colo.; 504 Federal Bldg., Salt Lake City, Utah; Grand Junction, Colo.

113. Hackman, R. J., Photogeologic map, Elk Ridge 2 quadrangle, San Juan County, Utah: 1 map. Nov. 8, 1954. 504 Federal Bldg., Salt Lake City, Utah; 468 New Customhouse, Denver, Colo.; Grand Junction, Colo. 
114. Halpenny, L. C., Letter of August 3 from L. C. Halpenny to Arizona State Commission, concerning the ground-water situation along the Gila River from Lateral 23 westward to the vicinity of Buckeye, Ariz.: September 15, 1954. 136 N. Park Ave., Tucson, Ariz.; 1242-G General Services Administration Bldg. , Washington, D. C.

115. Hansen, F. N., Irelan, Burdge, and Aertker, D. R. , Supplemental surface-water supplies report for the Vermillion River basin, La.: 50 p., 12 figs. May 6, 1954. 850 N. 5th Street, Baton Rougé, La.; 220 Jackson Parish Court House Bldg., Jonesboro, La.; 302 West 15th Street, Austin, Tex. ; Rooms 1242-L and 2238 General Services Administration Bldg. , Washington, D. C.

116. Harshbarger, J. W., and others., 28 preliminary geologic maps covering a part of the Navajo and Hopi Indian Reservations: November 5, 1954. 1033 General Services Administration Bldg. , Washington, D. C.; 136 North Park Ave., Tucson, Ariz. ; Navajo County Fairgrounds (P. O. Box 517), Holbrook, Ariz.; 468 New Customhouse, Denver, Colo.; 504 Federal Bldg. , Salt Lake City, Utah.

117. Hartshorn, J. H., Geologic reconnaissance in Longmeadow and East Longmeadow, Mass., with special reference to the relocation of Route 5 in Longmeadow: 6 p., 31 figs., 1 cross section, 1 geologic map. Sept. 30, 1954. Room 1, 270 Dartmouth St., Boston, Mass.; Massachusetts Department of Public Works, 100 Nashua St. , Boston, Mass.

118. Hartsook, J. K., Geologic map and structure sections of the Iniskin Peninsula and adjacent area of Alaska: 1 map, cross sections. Apr. 12, 1954. Brooks Memorial Mines Bldg. , University of Alaska, College, Alaska; Federal Bldg., Juneau, Alaska; 724 Appraisers Bldg., San Francisco, Calif: ; 210 E. F. Glover Bldg., Anchorage, Alaska.

119. Hazelwood, R. M., and Castle, R. O., Geologic interpretation of seismic data along the proposed relocation of Route 138; stations $59+00$ to $83+00$ in Brockton, Mass.: 2 p. , 3 pls. Apr. 26, 1954. Room 1, 270 Dartmouth St. , Boston, Mass.; Massachusetts Department of Public Works, 100 Nashua St. , Boston, Mass.

120. Heath, R. C., Results of ground-water studies on the western end of Fair Point Peninsula, Santa Rosa County, Fla.: 4 graphs, 1 table, no text. December 27, 1954. New Dining Hall Building, Florida State University, Tallahassee, Fla.; 1242-G General Services Administration Bldg., Washington, D. C.

121. Hemphill, W. R., Photogeologic map, Orange Cliffs 6 quadrangle, Wayne County, Utah: 1.map. February 15, 1954. 468 New Customhouse, Denver, Colo.; 504 Federal Bldg. , Salt Lake City, Utah; Grand Junction, Colo.
122. Hemphill, W. R., Photogeologic map, Stinking Spring Creek 10 quadrangle, Emery County, Utah: 1 map. July 14, 1954. 504 Federal Bldg. , Salt Lake City, Utah; 468 New Customhouse, Denver, Colo,; Grand Junction, Colo.

123. Hemphill, W. R., and Lewis, C. R., Photogeologic map, Desert Lake 15 quadrangle, Emery County, Utah: 1 map. July 14, 1954. 504 Federal Bldg., Salt Lake City, Utah; 468 New Customhouse, Denver, Colo.; Grand Junction, Colo.

124. Henderson, J. R., Photomosaic maps of radioactivity anomalies in Carbon and Sweetwater Counties, Wyo.: 5 maps. June 25, 1954. 724 Appraisers Bldg., San Francisco, Calif.; Menlo Park, Calif.; 468 New Customhouse, Denver, Colo.; Grand Junction, Colo.; Custer, S. Dak.; 504 Federal Bldg., Salt Lake City, Utah; Federal Bldg., Casper, Wyo.; Sheridan, Wyo.; Science Hall, University of Wyoming, Laramie, Wyo.; Worland, Wyo. ; Bureau of Mines, Rapid City, S. Dak. ; the following offices of the Atomic Energy Commission: Phoenix suboffice, Phoenix, Ariz.; Denver Explorations Branch, Denver Federal Center, Denver, Colo.; Grand Junction Operations Office, Grand Junction, Colo.; Ishpeming suboffice, Ishpeming, Mich.; Butte suboffice, Butte, Mont.; Buying Station, Shiprock, N. Mex.; Albuquerque suboffice, Albuquerque, N. Mex.; New York Raw Materials Office, New York, N. Y.; Hot Springs suboffice, Hot Springs, S. Dak.; Salt Lake Exploration Branch, Salt Lake City, Utah; Richfield suboffice, Richfield, Utah; Buying Station, Monticello, Utah; Douglas, suboffice, Douglas, Wyo.

125. Henderson, J. R., Total intensity aeromagnetic profiles in Olympic Peninsula, Wash.: 1 map. March 12,. 1954. 529 Post Office and Court House Bldg., Los Angeles, Calif.; 234 Federal Bldg. , Tulsa, Okla.; Room 213, 2520 Marconi Ave., Sacramento, Calif.; State Department of Conservation and Development, Division of Mines and Geology, 406 Transportation Bldg., Olympia, Wash.; 621 Post Office Bldg. , Portland, Oreg.

126. Hoare, J. M., and Coonrad, W. L., Preliminary geologic reconnaissance map of a portion of the lower Kuskokwim area, Alaska: 1 map. Sept. 7, 1954. 4 Homeward Pl., Menlo Park, Calif.; 724 Appraisers Bldg., San Francisco, Calif.; Federal Bldg., Juneau, Alaska; 210 E. F. Glover Bldg., Anchorage, Alaska; Brooks Memorial Mines Bldg., College, Alaska; Territorial Department of Mines, Juneau, Alaska.

127. Hofman, Walter, Briggs, R. C., and Littlefield, W. M. , Southern California Water Bulletin for 1953: 30 p., 5 figs. May 7, 1954. 429 United States Post Office and Court House, Los Angeles, Calif.; 2238 General Services Administration Bldg., Washington, D. C. 
128. Holland, P. H. , Diversions from Red River to Lake Dallas, Texas, and related channel losses, February and March 1954: 9 p. , 1 pl. , 4 figs. June 17, 1954. 320 West 15 th St., Austin, Texas; 2238 General Services Administration Bldg., Washington, D. C.

129. Hooker, Marjorie, Progress report (1953) on revision of Washington's Chemical analyses of igneous rocks (Geological Survey Professional Paper 99): 14 p. June 1, 1954.

130. Hosley, V. M., Photogeologic map, Carlisle 7 quadrangle, San Juan County, Utah: 1 map. Apr. 26, 1954. 504 Federal Bldg., Salt Lake City, Utah; 468 New Customhouse, Denver, Colo.; Grand Junction, Colo.

131. Hosley, V. M., Photogeologic map, Woodside 4 quadrangle, Emery and Carbon Counties, Utah: 1 map. July 14, 1954. 504 Federal Bldg., Salt Lake City, Utah; 468 New Customhouse, Denver, Colo.; Grand Junction, Colo.

132. Hunt, C. B:, Geologic map of La Sal Mountains, Utah: 1 map. July 28, 1954. Room 1220, Bldg. 25, Denver Federal Center, Denver, Colo.; 468 New Customhouse, Denver, Colo.; 807 Post Office and Courthouse, Los Angeles, Calif.; 504 Federal Bldg., Salt Lake City, Utah; Grand Junction, Colo.

133. Jackson, E. D., Howland, A. L., Peoples, J. W. and Jones, W. R., Geologic maps and sections of the eastern part of the Stillwater complex in Stillwater County, Mont.: 2 maps, 1 mine plan, 1 sheet of sections. July 16, 1954. South 157 Howard St. , Spokane, Wash.; Montana Bureau of Mines and Geology, Butte, Mont.

134. Johnson, F. A., Preliminary report on the water-power possibilities of the Seldovia River, Alaska: 17 p., 1 fig. January 1954. 244 Federal Bldg., Tacoma, Wash.; Federal Bldg. , Juneau, Alaska; 210 Glover Bldg. , Anchorage, Alaska; Mines Bldg. , College, Alaska; 1033 General Services Administration Bldg., Washington, D. C.

135. Johnson, P. W., Memorandum on ground-water conditions in parts of Tps. 10 and 11 S. , Rs. 23 and 24 W. , Yuma County, Ariz.: 5 p. February 23, 1954. 18 East McCormick St. , Tucson, Ariz.; 1242-G General Services Administration Bldg., Washington, D. C.

136. Jones, F. O., Landslide conditions along the Ferry County Highway paralleling Lake Roosevelt from Kettle Falls to the mouth of the Spokane River, Wash.: 35 p., 4 maps, 5 photographs. Mar. 31, 1954. South 157 Foward St., Spokane, Wash.; Office of the County Clerk, Republic, Ferry County, Wash.
137. Kachadoorian, Reuben, Hopkins, D. M., and Nichols, D. R. , Preliminary report of geologic factors affecting highway construction in the area between the Susitna and Maclaren Rivers, Alaska: 74 p., 8 figs., 2 tables. June 21, 1954. Brooks Memorial Mines Bldg. , University of Alaska, College, Alaska; Federal Bldg., Juneau, Alaska; E. F. Glover Bldg., Anchorage, Alaska.

138. Keech, C. F., and Case, R. L., Water levels prior to January 1, 1954 in observation wells in Nebraska: 543 p. December 27, 1954. 510 Rudge-Guenzel Building, Lincoln, Nebr.; 1242-G General Services Administration Bldg. , Washington, D. C. -

139. Keighton, W. B., The investigation of chemical quality of water in tidal rivers: 54 p. , 14 figs. , 6 tables. June 11, 1954. 1302 Custom House, $2 \mathrm{~d}$ and Chestnut Sts., Philadelphia, Pa.; Room 1242-L General Services Administration Bldg., Washington, D. C.

140. Keith, Arthur, and Sterrett, D. B., Geologic map of Morgantown quadrangle, N. C.: 1 map. July 28, 1954. 468 New Customhouse, Denver, Colo.; 13 Post Office Bldg., Knoxville, Tenn.; Office of the State Geologist, State Office Bldg., Raleigh, N. C.; Tennessee Geological Survey, Nashville, Tenn.; Virginia Geological Survey, Charlottesville, Va.; South Carolina Geological Survey, Columbia, S. C.

141. Keller, A. S., Petroleum possibilities of the Umiat area, 1950: 5 p., 1 pl. May 10, 1954. 2542 Dept. of Interior Bldg., Washington, D. C.; Office of the Inspector, Naval Petroleum Reserve No. 4, Fairbanks, Alaska.

142. Keller, A. S., and Detterman, R. L., Preliminary report on the stratigraphy and structure of the Shaviovik and Upper Sagavanirtok Rivers area, Alaska, 1951: 19 p., 5 pls. May 10, 1954. 2542 Dept. of Interior Bldg., Washington, D. C.; Office of the Inspector, Naval Petroleum Reserve No. 4, Fairbanks, Alaska.

143. Keller, A. S., and Morris, R. H., Preliminary report on the stratigraphy and structure of the Canning and Shaviovik Rivers area, 1952: 24 p., 7. pls. May 10, 1954. 2542 Dept. of Interior Bldg., Washington, D. C.; Office of the Inspector, Naval Petroleum Reserve No. 4, Fairbains, Alaska.

144. Keller, F., Jr., and Henderson, J. R., Jr., Aeromagnetic survey of Naval Petroleum Reserve No. 4 and adjacent areas, 1947: 15 p., 11 figs., 1 pl. May 10, 1954. 2542 Dept. of Interior Bldg., Washington, D. C.; Office of the Inspector, Naval Petroleum Reserve No. 4, Fairbanks, Alaska. 
145. Kent, B. H. , Photogeologic map, Circle Cliffs 13 quadrangle, Garfield and Kane Counties, Utah: 1 map. Sept. 30, 1954. 504 Federal Bldg., Salt Lake City, Utah; 468 New Customhouse, Denver, Colo.; Grand Junction, Colo.

146. Kent, B. H., Photogeologic map, Straight Cliffs 7 quadrangle, Kane County, Utah: 1 map. Sept. 30, 1954. 504 Federal Bldg., Salt Lake City, Utah; 468 New Customhouse, Denver, Colo.; Grand Junction, Colo.

147. Kent, B. H., and Condon, W. H., Photogeologic map, Orange Cliffs 15 quadrangle, Garfield and San Juan Counties, Utah: 1 map. Apr. 26, 1954. 504 Federal Bldg., Salt Lake City, Utah; 468 New Customhouse, Denver, Colo.; Grand Junction, Colo.

148. Kinkel, A. R., Jr., Hall, W. E., and Albers, J. P., Geologic maps of the Shasta copperzinc district, Shasta County, Calif.: 1 map, 4 sheets. Apr. 20, 1954. 4 Homeward Pl., Menlo Park, Calif.; Office of the Chief of the Califormia State Division of Mines, Ferry Bldg., San Francisco, Calif.

149. Knox, C. E., and Bradley, W. H., Current velocities in Sagadahoc Bay, Maine: 8 p., 20 figs., 10 tables, 1 map. July 27, 1954. Maine Department of Sea and Shore Fisheries, Vickery-Hill Bldg., Augusta, Maine; Office of the State Geologist, University of Maine, Orono, Maine.

150. Koschmann, A. H., Geologic map of Duke Island, southeastern Alaska: 1 map. Aug. 6, 1954. Brooks Memorial Mines Bldg. , University of Alaska, College, Alaska; Federal Bldg., Juneau, Alaska; 210 E. F. Glover Bldg., Anchorage, Alaska; 724 Appraisers Bldg., San Francisco, Calif.

151. Kover, A. N., Summary of porosity and permeability data, 1950: 5 p., 11 figs. May 10, 1954. 2542 Dept. of Interior Bldg., Washington, D. C.; Office of the Inspector, Naval Petroleum Reserve No. 4, Fairbanks, Alaska.

152. Krynine, P. D., Analysis of sand formation in a deformed geosyncline with special reference to northern Alaska, 1949: 5 p. , 3 figs. May 10, 1954. 2542 Dept. of Interior Bldg., Washington, D. C.; Office of the Inspector, Naval Petroleum Reserve No. 4, Fairbanks, Alaska.

153. Krynine, P. D., Petrography and reservoir characteristics of selected Tertiary and Cretaceous sandstone cores from Naval Petroleum Reserve No. 4, 1948: 31 p. , 13 figs. May 10, 1954. 2542 Dept. of Interior Bldg. , Washington, D. C. ; Office of the Inspector, Naval Petroleum Reserve No. 4, Fairbanks, Alaska.

154. Krynine, P. D., Petrology and reservoir properties of South Barrow test wells no. 1 and no. 2, 1949: 11 p., 5 figs. May 10, 1954. 2542 Dept. of Interior Bldg., Washington, D. C.; Office of the Insipector, Naval Petroleum Reserve No. 4, Fairbanks, Alaska.
155. Krynine, P. D. , Possible formation of reservoirs in Naval Petroleum Reserve No. 4, by vertical tectonic movements, 1952: 8 p., 2 figs. May 10 1954. 2542 Dept. of Interior Bldg., Washington, D. C.; Office of the Inspector, Naval Petroleum Reserve No. 4, Fairbanks, Alaska.

156. Krynine, P. D., Report on three specimens from South Barrow Test Well No. 1 with unusual permeability behavior, Jan. 1949: 6 p., 6 figs. May 10, 1954. 2542 Dept. of Interior Bldg., Washington, D. C.; Office of the Inspector, Naval Petroleum Reserve No. 4, Fairbanks, Alaska.

157. Krynine, P. D., Reservoir characteristics indicated by thin section analyses of sand cores from Umiat Test No. 1, 1947: 11 p., 1 fig. , 3 pls. May 10, 1954. 2542 Dept. of Interior Bldg., Washington, D. C. ; Office of the Inspector, Naval Petroleum Reserve No. 4, Fairbanks, Alaska.

158. Krynine, P. D., and Ferm, J. C., Petrography and reservoir characteristics of Umiat Test Well 9, 1952: 16 p., 10 figs. May 10, 1954. 2542 Dept. of Interior Bldg. , Washington, D. C; Office of the Inspector, Naval Petroleum Reserve No. 4, Fairbanks, Alaska.

159. Krynine, P. D., and Folk, R. L., Petrology of the Lisburne limestone, 1950: 18 p. , 7 figs. May 10, 1954. 2542 Dept. of Interior Bldg., Washington, D. C.; Office of the Inspector, Naval Petroleum Reserve No. 4, Fairbanks, Alaska.

160. Krynine, P. D., Folk, R. L., Rosenfeld, M. A., and Bowsher, A. L., Sr., Porosity and petrography of Lisburne limestone samples from the Kanayut, Nanushuk, and Itkillik Lakes area: 27 p. , 11 figs., 1 pl. May 10, 1954. 2542 Dept. of Interior Bldg., Washington, D. C.; Office of the Inspector, Naval Petroleum Reserve No. 4, Fa.irbanks, Alaska.

161. Lathram, E. H., Heavy mineral zonation of Cretaceous and Tertiary rocks of the central area of northern Alaska, 1949: 5 p., 5 figs. May 10, 1954. 2542 Dept. of Interior Bldg., Washington, D. C.; Office of the Inspector, Naval Petroleum Reserve No. 4, Fairbanks, Alaska.

162. Lathram, E. H., Revision of report by Robert E. Fellows, 1946, on significance and preliminary results of heavy mineral studies in northern Alaska, 1947: 7 p., 3 figs. May 10, 1954. 2542 Dept. of Interior Bldg. , Washington, D. C. ; Office of the Inspector, Naval Petroleum Reserve No. 4, Fairbanks, Alaska.

163. Lathram, E. H., and Keller, A. S., Discussion of the correlation of the South Barrow test wells, 1949: 5 p., 3 figs., 1 pl. May 10, 1954. 2542 Dept. of-Interior Bldg., Washington, D. C.; Office of the Inspector, Naval Petroleum Reserve No. 4, Fairbanks, Alaska. 
164. Laub, D. C., Copper and uranium mineralization in the Coyote mining district, Mora County, N. Mex.: 24 p., 13 figs. July 28, 1954.

165. Lawthers, Robert, Titanium resources of the world: 613 p. Mar. 12, 1954.

166. Lemke, R. W., Erskine, C. F., and Maughan, E. K., Preliminary geologic map of Portage quadrangle, Mont., surficial geology: 1 map. Apr. 26, 1954. 468 New Customhouse, Denver, Colo.; 315 Federal Bldg., Billings, Mont.; Montana Bureau of Mines and Geology, Butte, Mont.

167. Lindvall, R. M. , Preliminary map of the geology of the Boxelder quadrangle, Mont.: 1 map. June 1, 1954. 468 New Customhouse, Denver, Colo.; Office of the Supervising Geologist, Fuels Branch, Geological Survey, 315 Federal Bldg. , Billings, Mont.; Office of the Regional Geologist, Conservation Division, Geological Survey, 417 Electric Bldg., Treat Falls, Mont.; Office of the Director, State Bureau of Mines and Geology, Butte, Mont.

168. Loeblich, H. N., Progress of microfossil investigations, Naval Petroleum Reserve No. 4, Alaska, 1947: 9 p., 2 pls. May 10, 1954. 2542 Dept. of Interior Bldg., Washington, D. C.; Office of the Inspector, Naval Petroleum Reserve No. 4, Fairbanks, Alaska.

169. Loeblich, H. N., Progress report on microfossil investigations, Nov. 1948: 7 p., 3 pls. May 10, 1954. 2542 Dept. of Interior Bldg., Washington, D. C.; Office of the Inspector, Naval Petroleum Reserve No. 4, Fairbanks, Alaska.

170. Loeblich, H. N., Progress report of microfossil investigations, Naval Petroleum Reserve No. 4 , 1948: 6 p., 7 pls. May 10, 1954. 2542 Dept. of Interior Bldg., Washington, D. C.; Office of the Inspector, Naval Petroleum Reserve No. 4, Fairbanks, Alaska.

171. Loeblich, H. N., Recent stratigraphic revisions in Naval Petroleum Reserve No. 4, and correlations with the Canadian Cretaceous based on Foraminifera, 1950: 13 p. , 2 figs. May 10, 1954. 2542 Dept. of Interior Bldg., Washington, D. C.; Office of the Inspector, Naval Petroleum Reserve No. 4, Fairbanks, Alaska.

172. Loeblich, H. N., Summary of microfossil investigations, April 1948 to April 1949, with special reference to the Barrow and Simpson areas, 1949: 83 p., 1 fig., 2 pls. May 10, 1954. 2542 Dept. of Interior Bldg., , Washington, D. C.; Office of the Inspector, Naval Petroleum Reserve No. 4, Fairbanks, Alaska.

173. Loeltz, O. J., Hydraulic characteristics of aquifers penetrated by irrigation wells in the vicinity of Orovada, Humboldt County, Nev., 1953: 31 p. , 8 figs. May 10, 1954. 231 State Office Bldg., Carson City, Nev.; 1242-G General Services Administration Bldg., Washington, D. C.
174. Love, S. K., Industrial water supplies of the United States: 18 p. July 21, 1954.

Room 1242-L General Services Administration Bldg., Washington, D. C.

175. Lusczynski, N. J., and Spiegel, S. J., Average daily withdrawals of water for public supply from Kings, Queens, and Nassau Counties in Long Island, N. Y., from 1904 through 1953: 3 p. , 2 figs. August 5, 1954. 230 Old Colony Road, Mineola, L. I. , N. Y.; 1242-G General Services Administration Bldg., Washington, D. C.

176. Lusczynski, N. J., and Upson, J. E., Progress report on studies of salt-water encroachment on Long Island, N. Y., 1953: 7 p., 1 fig. January 25, 1954. 230 Old Country Road, Mineola, L. I., N. Y.; 1242-G General Services Administration Bldg., Washington, D. C.

177. McDaniels, L. L., Peak discharges on Bull Creek and tributaries, Scurry and Borden Counties, Texas, flood of April 12-13, 1954: 5 p. , 1 map. November 10, 1954. 302 West 15th Street, Austin, Tex. ; 1602 West Beauregard Street, San Angelo, Tex. ; 2238 General Services Administration Bldg. , Washington, D. C.

178. McGuinness, C. L., and Poland, J. F., Availability of primary or juvenile water for ordinary uses: 4 p. November 10, 1954. 2520 Marconi Ave., Sacramento, Calif.; 1242-G General Services Administration Bldg., Washington, D. C.

179. Maher, J. C., Ground-water conditions at Camp Livingston, Camp Beauregard, and Esler Field, La.: 43 p., 5 pls. February 23, 1954. 16 Geology Bldg., University of Louisiana, Baton Rouge, La.; 1242-G General Services Administration Bldg., Washington, D. C.

180. Maher, J. C., Ground-water conditions at Camp Claiborne, La.: 19 p., 7 pls. February 23, 1954. 16 Geology Bldg., University of Louisiana, Baton Rouge, La. ; 1242-G General Services Administration Bldg., Washington, D. C.

181. Mangus, M. D., Regional interpretation of the geology of the Kongakut-Firth Rivers area, Alaska, 1953: 24 p. , 1 pl. May 10, 1954. 2542 Dept. of Interior Bldg., Washington, D. C.; Office of the Inspector, Naval Petroleum Reserve No. 4, Fairbanks, Alaska.

182. Mangus, M. D., Detterman, R. L., Lachenbruch, M. C., Jr., Lachenbruch, A. H., Stratigraphy and structure of the Etivluk and Kuna Rivers area, Alaska, 1950: 15 p., 1 fig., 3 pls. May 10, 1954. 2542 Dept. of Interior Bldg., Washington, D. C.; Office of the Inspector, Naval Petroleum Reserve No. 4, Fairbanks, Alaska.

183. Marine, I. W., Ground-water levels in Delaware in 1952: 7 p. July 23, 1954. Post Office Bldg., Newark, Del.; 1242-G General Services Administration Bldg., Washington, D. C. 
184. Marshall, C. H., Photogeologic map, Bluff 3 quadrangle, San Juan County, Utah: 1 map. Nov. 8, 1954. 504 Federal Bldg., Salt Lake City, Utah; 468 New Customhouse, Denver, Colo.; Grand Junction, Colo.

185. Marshall, C. H., Photogeologic map, Desert Lake 16 quadrangle, Emery County, Utah: 1 map. Apr. 26, 1954. 504 Federal Bldg., Salt Lake City, Utah; 468 New Customhouse, Denver, Colo.; Grand Junction, Colo.

186. Marshall, C. H., and Rosendale, A. B., Structure of the Discovery anticline, 1953: $4 \mathrm{p}$. 1 fig., 1 pl. May 10, 1954. 2542 Dept. of Interior Bldg., Washington, D. C.; Office of the Inspector, Naval Petroleum Reserve No. 4, Fairbanks, Alaska.

187. Mason, B. J., Ground-water data collected in the Missouri River Basin units in Kansas during 1953: 34 p., 2 figs. September 15, 1954. 510 Rudge-Guenzel Bldg., Lincoln, Nebr.; University of Kansas, Lawrence, Kans. ; 1242-G General Services Administration Bldg., Washington, D. C.

188. Mason, B. J., and Underwood, S. J., Groundwater data collected in the Missouri River Basin units in Kansas during 1952: 81 p. 11 figs. February 23, 1954. 510 RudgeGuenzel Bldg., Lincoln, Nebr.; University of Kansas, Lawrence, Kans.; 1242-G General Services Administration Bldg., Washington, D. C.

189. Maynard, J. E., Geologic interpretation of seismic data, relocation of Route 3; cut, stations 364-382 in Billerica, Mass.: 2 p., 3 pls. Apr. 26, 1954. Room 1, 270 Dartmouth St., Boston, Mass.; Massachusetts Department of Public Works, 100 Nashua St. , Boston, Mass.

190. Maynard, J. E., Geologic and seismic investigations, relocation of Route 3, grade separation at Route 62, southeast ramp in Bedford, Mass.: 2 p. , 2 pls. July 27, 1954. Room 1, 270 Dartmouth St. , Boston, Mass.; Massachusetts Department of Public Works, 100 Nashua St., Boston, Mass.

191. Maynard; J. E., Geologic interpretation of seismic data, relocation of Route 3 at Route 62, northwest ramps and approach for Route 62 in Bedford, Mass., supplementary report: 2 p. , 3 pls. July 27, 1954. Room 1, 270 Dartmouth St., Boston, Mass.; Massachusetts Department of Public Works, 100 Nashua St. , Boston, Mass.

192. Maynard, J. E., Geologic and seismic investigations for relocation of Route 8; cut, stations 0-18 in Sandisfield, Mass.: 2 p., 3 pls. Apr. 26, 1954. Room 1, 270 Dartmouth St., Boston, Mass.; Massachusetts Department of Public Works, 100 Nashua St., Boston, Mass.
193. Maynard, J. E., Geologic and seismic investigations for relocation of Route 128 at Route $1 \mathrm{~A}$ in Dedham, Mass.: 2 p., 4 pls. July 27, 1954. Room 1, 270 Dartmouth St., Boston, Mass.; Massachusetts Department of Public Works, 100 Nashua St. , Boston, Mass.

194. Maynard, J. E., Geologic and seismic investigations for relocation of Route 128 near Route 28 in Quincy, Mass.: 2 p., 3 pls. June 1, 1954. Room 1, 270 Dartmouth St. , Boston, Mass.; Massachusetts Department of Public Works, 100 Nashua St., Boston, Mass.

195. Maynard, J. E., Geologic and seismic investigations for southeast expressway, stations 600 603 in Quincy, Mass.: 2 p., , 2 pls. July 27, 1954. Room 1, 270 Dartmouth St., Boston, Mass.; Massachusetts Department of Public Works, 100 Nashua St. , Boston, Mass.

196. Maynard, J. E., and Hazlewood, R. M. , Geologic interpretation of seismic data, relocation of Route 102 in Lee, Mass., proposed cut, stations 30-36: 2 p., 1 pl. July 27, 1954. Room 1, 270 Dartmouth St., Boston, Mass.; Massachusetts Department of Public Works, 100 Nashua St. , Boston, Mass.

197. Maynard, J. E., and Linehan, Rev. Daniel, Geologic and seismic investigations for relocation of Route 20 (Springfield Bypass) Alden Street to Chicopee River, proposed cuts, stations 783-788, and 790-796 in Ludlow, Mass.: 3 p., 2 pls. July 27, 1954. Room 1, 270 Dartmouth St. , Boston, Mass.; Massachusetts Department of Public Works, 100 Nashua St. , Boston, Mass.

198. Maynard, J. E., and Miller, Raymond, Geologic and seismic investigations for relocation of Route 138, Brockton-Avon town line, prospective cut, stations $193+00$ in Brockton to $8+00$ in Avon, Mass.: 2 p., 2 pls. July 14, 1954. Room 1, 270 Dartmouth St., Boston, Mass.; Massachusetts Department of Public Works, 100 Nashua St., Boston, Mass.

199. Maynard, J. E., and Miller, Raymond, Geologic and seismic investigations for relocation of Route 138 in Brockton, Mass., prospective cut, stations 169 to 180: 2 p., 2 pls. Apr. 26, 1954. Room 1, 270 Dartmouth St., Boston, Mass.; Massachusetts Department of Public Works, 100 Nashua St. , Boston, Mass.

200. Meuschke, J. L., and Books, K. G., Total intensity aeromagnetic map of central and western Kittson County, Minn.: 1 map. Oct. 7, 1954. Minnesota Geological Survey, Pillsbury Hall, University of Minnesota, Minneapolis, Minn.; Bureau of Mines, Federal Bldg., Duluth, Minn.; 2908 Colfax Ave. South, Minneapolis, Minn.; Division of Lands and Minerals, Hibbing, Minn. 
201. Meuschke, J. L., and Books, K. G., Total intensity aeromagnetic map of eastern Kittson and western Roseau Counties, Minn.: 1 map. Oct. 7, 1954. Minnesota Geological Survey, Pillsbury Hall, University of Minnesota, Minneapolis, Minn.; Bureau of Mines, Federal Bldg., Duluth, Minn.; 2908 Colfax Ave., South, Minneapolis, Minn.; Division of Lands and Minerals, Hibbing, Minn.

202. Meuschke, J. L., and Books, K. G., Total intensity aeromagnetic map of eastern Marshall and northwestern Beltrami Counties, Minn.: 1 map. Oct. 7, 1954. Minnesota Geological Survey, Pillsbury Hall, University of Minnesota, Minneapolis, Minn.; Bureau of Mines, Federal Bldg., Duluth, Minn.; 2908 Colfax Ave., South, Minneapolis, Minn.; Division of Lands and Minerals, Hibbing, Minn.

203. Meuschke, J. L., and Books, K. G., Total intensity aeromagnetic map of central Marshall and westërn Pennington Counties, Minn.: 1 map. Oct. 7, 1954. Minnesota Geological Survey; Pillsbury Hall, University of Minnesota, Minneapolis, Minn.; Bureau of Mines, Federal Bldg., Duluth, Minn.; 2908 Colfax Ave., South, Minneapolis, Minn.; Division of Lands and Minerals, Hibbing, Minn.

204. Meuschke, J. L., and Books, K. G., Total intensity aeromagnetic map of western Marshall and northwestern Polk Counties, Minn.: 1 map. Oct. 7, 1954. Minnesota Geological Survey, Pillsbury Hall, University of Minnesota, Minneapolis, Minn.; Bureau of Mines, Federal Bldg., Duluth, Minn.; 2908 Colfax Ave., South, Minneapolis, Minn.; Division of Lands and Minerals, Hibbing, Minn.

205. Meuschke, J. L., and Books, K. G., Total intensity aeromagnetic map of eastern Pennington, northwestern Red Lake, west-central Beltrami, and northern Clearwater Counties, Minn.: 1 map. Oct. 7, 1954. Minnesota Geological Survey, Pillsbury Hall, University of Minnesota, Minneapolis, Minn.; Bureau of Mines, Federal Bldg., Duluth, Minn.; 2908 Colfax Ave., South, Minneapolis, Minn.; Division of Lands and Minerals, Hibbing, Minn.

206. Meuschke, J. L., and Books, K. G., Total intensity aeromagnetic map of eastern Roseau County, Minn.: 1 map. Oct. 7, 1954. Minnesota Geological Survey, Pillsbury Hall, University of Minnesota, Minneapolis, Minn.; Bureau of Mines, Federal Bldg., Duluth, Minn.; 2908 Colfax Ave., South, Minneapolis, Minn.; Division of Lands and Minerals, Hibbing, Minn.

207. Meuschke, J. L., and Books, K. G., Total intensity aeromagnetic map of western Polk County, Minn.: 1 map. Oct. 7, 1954. Minnesota Geological Survey, Pillsbury Hall, University of Minnesota, Minneapolis, Minn.; Bureau of Mines, Federal Bldg., Duluth, Minn.; 2908 Colfax Ave., South, Minneapolis, Minn.; Division of Lands and Minerals, Hibbing, Minn.
208. Meuschke, J. L., and Books, K. G., Total intensity aeromagnetic map of western Red Lake and central Polk Counties, Minn.: 1 map. Oct. 7, 1954. Minneśota Geological Survey, Pillsbury Hall, University of Minnesota, Minneapolis, Minn.; Bureau of Mines, Federal Bldg. , Duluth, Minn.; 2908 Colfax Ave., South, Minneapolis, Minn.; Division of Lands and Minerals, Hibbing, Minn.

209. Miller, C. F., Photogeologic map, Desert Lake 2 quadrangle, Emery and Carbon Counties, Utah: 1 map. July 14, 1954. 504 Federal Bldg., Salt Lake City, Utah; 468 New Customhouse, Denver, Colo.; Grand Junction, Colo.

210. Miller, C. F., Photogeologic map, Desert Lake 6 quadrangle, Emery County, Utah: 1 map. Sept. 30, 1954. 504 Federal Bldg., Salt Lake City, Utah; 468 New Customhouse, Denver, Colo.; Grand Junction, Colo.

211. Miller. C. F., Photogeologic map, Desert Lake 12 quadrangle, Emery County, Utah: 1 map. Sept. 30, 1954. 504 Federal Bldg., Salt Lake City, Utah; 468 New Customhouse, Denver, Colo.; Grand Junction, Colo.

212. Miller, C. F., Photogeologic map, Tidwell 12 quadrangle, Emery County, Utah: 1 map. July 27, 1954. 504 Federal Bldg., Salt Lake City, Utah; 468 New Customhouse, Denver, Colo.; Grand Junction, Colo.

213. Mineral Deposits Branch, Drill-hole logs and index map of holes drilled on Blue Mesa, Mesa County, Colo.: 1 map, drill-hole logs. Oct. 1, 1954. Grand Junction, Colo.

214. Mineral Deposits Branch, Map showing the distribution of occurrences of uranium-bearing material and of anomalous radioactivity in the Jefferson City quadrangle, Jefferson County and Lewis and Clark County, Mont.: 1 map. June 17, 1954. South 157 Howard St., Spokane, Wash.; 468 New Customhouse, Denver, Colo.; 504 Federal Bldg., Salt Lake City, Utah; State Bureau of Mines and Geology, Butte, Mont.

215. Morris, R. H., Heavy mineral analysis of the Barrow, Cape Simpson, and Umiat areas, 1950: 6 p., 6 figs., 1 pl. May 10, 1954. 2542 Dept. of Interior Bldg., Washington, D. C.; Office of the Inspector, Naval Petroleum Reserve No. 4, Fairbanks, Alaska.

216. Morris, R. H. , Heavy mineral studies of northern Alaska, 1952: 18 p., 2 pls. May 10, 1954. 2542 Dept. of Interior Bldg., Washington, D. C.; Office of the Inspector, Naval Petroleum Reserve No. 4, Fairbanks, Alaska.

217. Mower, R. W., Records of wells, ground-water levels, and ground-water withdrawals in the Lower Goose Creek basin, Cassia County, Idaho: $92 \mathrm{p}$., 1 pl., 2 figs. January 29,1954 . 607 Post Office Bldg., Portland, Oreg.; 209 Fidelity Bldg. and 429 Federal Bldg., Boise, Idaho; 204 Federal Bldg., Idaho Falls, Idaho; 503A and 504 Federal Bldg., Salt Lake City, Utah; Office of the Idaho State Reclamation Engineer, State House, Boise, Idaho; 1242-G General Services Administration Bldg., Washington, D. C. 
218. Murphy, J. J., Salinity studies on estuaries of the Eastern Shore of Maryland: 39 p., 6 figs., 16 tables. April 4, 1954. P. O. Box 4355, Oklahoma City, Okla.; 1242-L General Services Administration Bldg., Washington, D. C.

219. Nace, R. L., Ground-water resources of the Raft River basin, Cassia County, Idaho-A summary of unpublished data: $12 \mathrm{p}$. February 23, 1954. 720 Idaho St. , Boise, Idaho; 1242-G General Services Administration Bldg., Washington, D. C.

220. Nelson, A. E., Wiesnet, D. R., and Postel, A. W. Pre-Cambrian geology of the Chateaugay quadrangle, Franklin County, N. Y.: 1 map. Mar. 12, 1954. Beltsville, Md.; State Geological and Natural History Surveys, State Education Bldg., University of the State of New York, Albany, N. Y.

221. Orkild, P. P., Photogeologic map, Desert Lake 8 quadrangle, Emery County, Utah: 1 map. July 27, 1954. 504 Federal Bldg., Salt Lake City, Utah; 468 New Customhouse, Denver, Colo.; Grand Junction, Colo.

222. Orkild, P. P., Photogeologic map, Woodside 5 quadrangle, Emery County, Utah: 1 map. Sept. 30, 1954. 504 Federal Bldg., Salt Lake City, Utah; 468 New Customhouse, Denver, Colo.; Grand Junction, Colo.

223. Orkild, P. P., Photogeologic map, Woodside 12 quadrangle, Emery County, Utah: 1 map. Mar. 12, 1954. 504 Federal Bldg., Salt Lake City, Utah; 468 New Customhouse, Denver, Colo.

224. Otton, E. G., and others., Graphs showing percentage composition of sediments from water-bearing formations in southern Maryland, and maps showing the altitude of the base of sediments of Miocene age, and hardness of water in sediments of Cretaceous age, in the same area: December 27, 1954. 103 Latrobe Hall, Johns Hopkins University, Baltimore, Md.; 1242-G General Services Administration Bldg., Washington, D. C.

225. Parker, R. L., Alunitic alteration at Marysville, Utah: 114 p., 9 pls., 17 figs. July 14, 1954. 504 Federal Bldg., Salt Lake City, Utah.

226. Patton, W. W., Jr., Geological results of test pit operations at Cape Simpson, Alaska, 1948: 4 p., 2 figs., 1 pl. May 10, 1954. 2542 Dept. of Interior Bldg., Washington, D. C.; Office of the Inspector, Naval Petroleum Reserve No. 4, Fairbanks, Alaska.

227. Patton, W. W., Jr., Brosge, W. P., and Mangus, M. D., Preliminary report on the geology of the Okokmilage and John Rivers area, Alaska, 1951: 13 p., 1 fig., 4 pls. May 10, 1954. 2542 Dept. of Interior Bldg. Washington, D. C.; Office of the Inspector, Naval Petroleum Reserve No. 4, Fairbanks, Alaska.
228. Patton, W. W., Jr., and Keller, A. S., Stratigraphy and structure of the upper Siksikpuk-Nanushuk Rivers area, Alaska, 1951: 20 p., 3 figs., 4 pls. May 10, 1954. 2542 Dept. of Interior Bldg., Washington, D. C.; Office of the Inspector, Naval Petroleum Reserve No. 4, Fairbanks, Alaska.

229. Patton, W. W., Jr., and Tailleur, I. L., Stratigraphy and structure of the Okpikruak and Kiruktagiak Rivers area, Alaska, 1950: 17 p. , 1 fig., 3 pls. May 10, 1954. 2542 Dept. of Interior Bldg., Washington, D. C.; Office of the Inspector, Naval Petroleum Reserve No. 4, Fairbanks, Alaska.

230. Payne, T. G., Areal evaluation of petroleum possibilities of major stratigraphic units in northern Alaska, 1948: 16 p., 10 pls. May 10, 1954. 2542 Dept. of Interior Bldg., Washington, D. C.; Office of the Inspector, Naval Petroleum Reserve No. 4, Fairbanks, Alaska.

231. Payne, T. G., Revisions of the facies patterns of NPR-4 and adjoining areas, 1950: 7 p., 14 figs. May 10, 1954. 2542 Dept. of Interior Bldg., Washington, D. C. ; Office of the Inspector, Naval Petroleum Reserve No. 4, Fairbanks, Alaska.

232. Payne, T. G., Sedimentation analysis of recent drilling developments and geologic field work, 1949: 2 p., 7 figs. May 10, 1954. 2542 Dept. of Interior Bldg., Washington, D. C.; Office of the Inspector, Naval Petroleum Reserve No. 4, Fairbanks, Alaska.

233. Payne, T. G., Myers, W. H., and Bergquist, H. R. An interpretation of the subsurface stratigraphy of Naval Petroleum Reserve No. 4, 1950: 1 p., 5 figs., 1 pl. May 10, 1954. 2542 Dept. of Interior Bldg., Washington, D. C.; Office of the Inspector, Naval Petroleum Reserve No. 4, Fairbanks, Alaska.

234. Payne, T. G., Warner, L. A., Kirschner, C. E., Gryc, G., Stefansson, K., Webber, E. J., Fellows, R. E., Chapman, R. M., and Bressler, C. T., Stratigraphy and structure of the area of the Killik, Chandler, Anaktuvuk, and Colville Rivers, Alaska: 30 p., 6 figs., 8 pls. May 10, 1954. 2542 Dept. of Interior Bldg., Washington, D. C.; Office of the Inspector, Naval Petroleum Reserve No. 4, Fairbanks, Alaska.

235. Pennsylvania State College, Core analyses report on Simpson Test Well No. 1, 1948: 8 p., 2 figs. May 10, 1954. 2542 Dept. of Interior Bldg., Washington, D. C.; Office of the Inspector, Naval Petroleum Reserve No. 4, Fairbanks, Alaska.

236. Pennsylvania State College, with comments by E. H. Lathrum, Core analysis on core samples from South Barrow Test Well No. 1, Nov. 1948: 4 p., 2 figs. May 10, 1954. 2542 Dept. of Interior Bldg., Washington, D. C.; Office of the Inspector, Naval Petroleum Reserve No. 4, Fairbanks, Alaska. 
237. Pennsylvania State College Laboratory, Core analysis on core samples from South Barrow Test Well No. 2, 1949: 2 p., 1 fig. May 10, 1954. 2542 Dept. of Interior Bldg., Washington, D. C. ; Office of the Inspector, Naval Petroleum Reserve No. 4, Fairbanks, Alaska.

238. Peoples, J. W., Howland, A. L., Jones, W. R., and Flint, Delos, Geologic map, sections, and map of underground workings of the Mountain View Lake area, Stillwater County, Mont.: 2 maps, 8 sections. Feb. 15, 1954. South 157 Howard St., Spokane, Wash.; Montana Bureau of Mines and Geology, Butte, Mont.

239. Phillips, K. N., Progress report on operation of gaging stations for Fish Commission of Oregon, 1950-53: 58 p., 1 map. November 10, 1954. 1001 Lloyd Bldg., Portland, Oreg.; 2238 General Services Administration Bldg. , Washington, D. C.

240. Plafker, George, Geologic investigations of proposed power sites at Cooper, Grant, Ptarmigan, and Crescent Lakes, Alaska: 38 p., 1 fig. , 4 pls. Nov. 3, 1954. 4 Homeward P1., Menlo Park, Calif.; 724 Appraisers Bldg. , San Francisco, Calif.; 117 Federal Bldg., Juneau, Alaska; Brooks Memorial Mines Bldg., College, Alaska;210 E. F. Glover Bldg. , Anchorage, Alaska; Territorial Department of Mines, Juneau, Alaska.

241. Plafker, Gèorge, and Miller, Don J., Reconnaissance geology of the Malaspina district, Alaska: 15 p., 1 map. Aug. 16, 1954. 4 Homeward Pl., Menlo Park, Calif.; 724 Appraisers Bldg., San Francisco, Calif.; Federal Bldg., Juneau, Alaska; 210 Glover Bldg. , Anchorage, Alaska; Brooks Memorial Mines Bldg., College, Alaska.

242. Platt, J. N., Photogeologic map, Carlisle 11 quadrangle, San Juan County, Utah: 1 map. Nov. 8, 1954. 504 Federal Bldg., Salt Lake City, Utah; 468 New Customhouse, Denver, Colo.; Grand Junction, Colo.

243. Platt, J. N., Photogeologic map, Carlisle 13 quadrangle, San Juan and Garfield Counties, Utah: 1 map. July 27, 1954. 504 Federal Bldg., Salt Lake City, Utah; 468 New Customhouse, Denver, Colo.; Grand Junction, Colo.

244. Platt, J. N., Photogeologic map, Orange Cliff's 16 quadrangle, Garfield and San Juan Counties, Utah: 1 map. July 27, 1954. 504 Federal Bldg., Salt Lake City, Utah; 468 New Customhouse, Denver, Colo.; Grand Junction, Colo.

245. Plummer, H. J., with comments by H. N. Loeblich, Stratigraphy and paleontology in the Simpson area, Nov. 1948: 25 p. May 10, 1954. 2542 Dept. of Interior Bldg., Washington, D. C.; Office of the Inspector, Naval Petroleum Reserve No. 4, Fairbanks, Alaska.
246. Poland, J. F., and Dutcher, L. C., Second memorandum on the flow of Agua Caliente Spring after road construction at Palm Springs, Calif.: 8 p., 1 fig. February 23, 1954. 2520 Marconi Ave., Sacramento, Calif.; 221 Redondo Ave., Long Beach, Calif.; 1242-G General Services Administration Bldg., Washington, D. C.

247. Postel, A. W., Dodson, C. L., and Carswell, L. C., Geologic map of the Loon Lake quadrangle, N. Y. 1 map. Mar. 12, 1954. Beltsville, Md.; State Geological and Natural History Survey, State Education Bldg., University of the State of New York, Albany, N. Y.

248. Potter, D. B., High alumina metamorphic rocks of the Kings Mountain district, North Carolina and South Carolina: 201 p., 31 figs., 8 pls., 10 tables. July 28, 1954.

249. Powell, W. J., Ground water at Towaoc, Colo.: 22 p., 1 pl., 5 figs. August 5, 1954. Denver Federal Center, Denver, Colo.; 1242-G General Services Administration Bldg., Washingtor, D. C.

250. Ray, R. G., and Fischer, W. A., Stratigraphy and structure of the area of Maybe Creek: 10 p. , 4 pls. May 10, 1954. 2542 Dept. of Interior Bldg., Washington, D. C.; Office of the Inspector, Naval Petroleum Reserve No. 4, Fairbanks, Alaska.

251. Reed, J. C., Jr., Geologic map of the Mt. McKinley quadrangle, Alaska: 1 map. Oct. 29, 1954. 2650 Department of Interior Bldg. , Washington, D. C.

252. Reed, J. C., Jr., Photogeologic map, Straight Cliffs 9 quadrangle, Kane County, Utah: 1 map. Sept. 30, 1954. 504 Federal Bldg., Salt Lake City, Utah; 468 New Customhouse, Denver, Colo.; Grand Junction, Colo.

253. Remson, Irwin, Hydrologic studies at Seabrook, N. J.: 156 p., 6 pls., 23 figs. June 17, 1954. Seabrook Farms, N. J.; 432 Post Office Bldg. , Trenton, N. J. ; 1242-G General Services Administration Bldg., Washington, D. C.

254. Remson, Irwin, and Fox, G. S., Some unreliable types of ground-water observation wells: $14 \mathrm{p}$., 3 figs. November 10, 1954. Seabrook, N. J.; 432 Post Office Bldg., Trenton, N. J.; 1242-G General Services Administration Bldg. , Washington, D. C.

255. Rhodehamel, E. C., An interpretation of the pre-Pleistocene geomorphology of a portion of the Saginaw lowland: 163 p., 11 pls. , 8 figs. March 31, 1954. 418 Capitol Savings and Loan Bldg. , 112 E. Allegon St. , Lansing, Mich.

256. Roadifer, R. E., Geology of the Eureka pegmatite, Pennington County, S. Dak.: 22 p. 1 illus. July 14, 1954. 468 New Customhouse, Denver, Colo.; Library, South Dakota School of Mines, Rapid City, S. Dak.; South Dakota Geological Survey, Vermillion, S. Dak. 
257. Roberts, T. G., and Robinson, Florence, The subsurface stratigraphy and structure of the Simpson area, 1950: 5 p., 2 figs., 2 pls. May 10, 1954. 2542 Dept. of Interior Bldg. , Washington, D. C.; Office of the Inspector, Naval Petroleum Reserve No. 4, Fairbanks, Alaska.

258. Robinson, Florence, and Roberts, T. G., Suggested correlation in Simpson Seeps region, 1949: 3 p., 1 pl. May 10, 1954. 2542 Dept. of Interior Bldg., Washington, D. C.; Office of the Inspector, Naval Petroleum Reserve No. 4, Fairbanks, - Alaska.

25๑. Rogers, A. S., The physical behavior and geologic control of radon in mountain streams: 58 p., 4 figs. October 7, 1954.

260. Sable, E. G., A new interpretation of the Driftwood anticline, 1952: 5 p., 2 pls. May 10, 1954. 2542 Dept. of Interior Bldg., Washington, D. C.; Office of the Inspector, Naval Petroleum Reserve No. 4, Fairbanks, Alaska.

261. Sable, E. G., Shaling studies in the western part of NPR-4 and adjoining areas, 1952: 7 p., 5 figs. May 10, 1954. 2542 Dept. of Interior Bldg., Washington, D. C.; Office of the Inspector, Naval Petroleum Reserve No. 4, Fairbanks, Alaska.

262. Sable, E. G., Dutro, J. T., Jr., and Morris, R. H., Preliminary report on the stratigraphy and structure of the Driftwood-Noluk area, Alaska, 1951: 28 p., 4 pls. May 10, 1954. 2542 Dept. of Interior Bldg., Washington, D. C.; Office of the Inspector, Naval Petroleum Reserve No. 4, Fairbanks, Alaska.

263. Sable, E. G., and Mangus, M. D., Stratigraphy and structure of Driftwood anticline, 1951: 9 p., 2 pls. May 10, 1954. 2542 Dept. of Interior Bldg., Washington, D. C.; Office of the Inspector, Naval Petroleum Reserve No. 4, Fairbanks, Alaska.

264. Sable, E. G., and Mangus, M. D., Stratigraphy and structure of the upper Utukok-Kokolik Rivers area, Alaska, 1951: 19 p., 2 pls. May 10, 1954. 2542 Dept. of Interior Bldg., Washington, D. C.; Office of the Inspector, Naval Petroleum Reserve No. 4, Fairbanks, Alaska.

265. Sawyer, R. M., A progress report on streamflow investigations in Suffolk County, Long Island, N. Y., 1948-1952: 127 p. , 35 figs. 1 map. December 23, 1954. 526 Federal Bldg., Albany, N. Y.; 230 Old County Road, Mineola, N. Y.; 136 Canal St., Ellenville, N. Y.; 702 First National Bank Bldg., Ithaca, N. Y.; 2238 General Services Administration Bldg. , Washington, D. C.

266. Scheid, V. E., Stockton and Stanley Hill clay deposits, Kootenai County, Idaho: 24 p., 3 illus., 4 tables, appendix of 26 p. Apr. 26, 1954. South 157 Howard St., Spokane, Wash.; Idaho Bureau of Mines and Geology, Moscow, Idaho.
267. Scheid, V. E., and Hosterman, J. W., Bovill clay deposit, Latah County, Idaho: $25 \mathrm{p}$. 4 illus., 2 tables. Apr. 26, 1954. South 157 Howard St., Spokane, Wash.; Idaho Bureau of Mines and Geology, Moscow, Idaho.

268. Scheid, V. E., and Hosterman, J. W., CanfieldRodgers high-alumina clay deposit, Latah County, Idaho: 28 p., 2 illus., 1 table. Apr. 26, 1954. South 157 Howard St., Spokane, Wash.; Idaho Bureau of Mines and Geology, Moscow, Idaho.

269. Scheid, V. E., Sohn, I. G., and Hosterman, J. W., Camas Prairie clay deposits, Lewis and Idaho Counties, Idaho: 21 p., 2 illus., 2 tables. Apr. 26, 1954. South 157 Howard St., Spokane, Wash.; Idaho Bureau of Mines and Geology, Moscow, Idaho.

270. Scheid, V. E., Sohn, I. G., and Hosterman, J. W. Deary high-alumina clay deposit, Latah County, Idaho: 30 p., 3 illus., 1 table. Apr. 26, 1954. South 157 Howard St., Spokane, Wash.; Idaho Bureau of Mines and Geology, Moscow, Idaho.

271. Scheid, V. E., Hosterman, J. W., and Sohn, I. G. Excelsior high-alumina clay deposit, Spokane, Wash.: 77 p., 6 illus. Apr. 26, 1954. South 157 Howard St., Spokane, Wash.; Idaho Bureau of Mines and Geology, Moscow, Idaho.

272. Scheid, V. E., Hosterman, J. W., and Sohn, I. G., Olsen high-alumina and high-iron clay deposits, Latah County, Idaho: 25 p., 8 illus., 1 table. Apr. 26, 1954. South 157 Howard St., Spokane, Wash.; Idaho Bureau of Mines and Geology, Moscow, Idaho.

273. Scheid, V. E. , Hosterman, J. W., Sohn, I. G., Stanford clay deposit, Latah County, Idaho: 27 p., 2 illus., 1 table. Apr. 26, 1954. South 157 Howard St., Spokane, Wash.; Idaho Bureau of Mines and Geology, Moscow Idaho.

274. Schlocker, Julius, Radbruch, D. H., and Bonilla, M. G., Bedrock-surface map of the San Francisco City area, Calif.: 1 map. Oct. 27, 1954. 4 Homeward Pl., Menlo Park, Calif.; 724 Appraisers Bldg., San Francisco, Calif.; California State Division of Mines, Ferry Bldg., San Francisco, Calif.

275. Schroeder, M. C., Stratigraphy of the outcropping formations in southern Florida: $20 \mathrm{p}$. November 10, 1954. Dinner Key, South Bayshore Drive, Miami, Fla.; 1242-G General Services Administration Bldg., Washington, D. C.

276. Scott, J. M., Photogeologic map, Carlisle 2 quadrangle, San Juan County, Utah: 1 map. Apr. 26, 1954. 504 Federal Bldg., Salt Lake City, Utah; 468 New Customhouse, Denver, Colo.; Grand Junction, Colo.

277. Scott, J. M., Photogeologic map, Carlisle 10 quadrangle, San Juan County, Utah: 1 map. Feb. 15, 1954. 468 New Customhouse, Denver, Colo.; 504 Federal Bldg., Salt Lake City, Utah; Grand Junction, Colo. 
278. Scott, J. M., Photogeologic map, Castle Dale 16 quadrangle, Emery County, Utah: 1 map. Nov. 8, 1954. 504 Federal Bldg., Salt Lake City, Utah; 468 New Customhouse, Denver, Colo.; Grand Junction, Colo.

279. Scott, J. M., Photogeologic map, Desert Lake 1 quadrangle, Emery and Carbon Counties, Utah: 1 map. Nov. 8, 1954. 504 Federal Bldg., Salt Lake City, Utah; 468 New Customhouse, Denver, Colo.; Grand Junction, Colo.

280. Scott, J. M., Photogeologic map, Kaiparowits 8 quadrangle, Garfield County, Utah: 1 map. Jan. 11, 1954. 504 Federal Bldg., Salt Lake City, Utah; 468 New Customhouse, Denver, Colo.; Grand Junction, Colo.

281. Scott, J. M., Photogeologic map, Stinking Spring Creek 1 quadrangle, Emery County, Utah: 1 map. July 14, 1954. 504 Federal Bldg. , Salt Lake City, Utah; 468 New Customhouse, Denver, Colo.; Grand Junctioı, Colo.

282. Scott, J. M., Photogeologic map, Straight Cliffs 2 quadrangle, Kane County, Utah: 1 map. Jan. 11, 1954. 504 Federal Bldg., Salt Lake City, Utah; 468 New Customhouse, Denver, Colo.; Grand Junction, Colo.

283. Shapiro, Leonard, and Brannock, W. W., Field method for the determination of titanium in rocks: 7 p. Jan. 11, 1954.

284. Simpson, H. E., Geology of an area about Yankton, S. Dak.: 317 p. , 19 figs., 22 pls., 2 maps. July 28, 1954. Room 1220, Bldg. 25, Denver Federal Center, Denver, Colo.; Sterling Memorial Library, Yale University, New Haven, Conn.

285. Sims, P. K. , Drake, A. A., and Moench, R. H., Preliminary geologic and vein maps of part of the Central City district, Gilpin and Clear Creek Counties, Colo.: 7 p., 3 figs. Jan. 11, 1954. 468 New Customhouse, Denver, Colo.

286. Sims, P. K. , Tooker, E. W., Osterwald, F. W., Geologic maps of the Eureka Gulch area, Gilpin County, Colo.: 3 p., 3 illus. Feb. 15, 1954. 468 New Customhouse, Denver, Colo.

287. Sinnott, Allen, and Tibbits, G. C., Jr., Geology and ground-water resources of the Eastern Shore Peninsula, Va.: 33 p. November 10, 1954. Observatory Road, University of Virginia, Charlottesville, Va.; 1242-G General Services Administration Bldg., Washington, D. C.

288. Sisco, H. G. , Records of wells, water-level fluctuations, and ground-water withdrawals in the Aberdeen-Springfield area, Bingham and Power Counties, Idaho: 50 p., 1 pl., 1 fig. November 1954. 1033 General Services Administration Bldg. Washington, D. C. ; Interior Department Building, $1001 \mathrm{NE}$ Lloyd Boulevard, Portland, Oreg. ; 209 Fidelity Bldg. , Boise, Idaho; 204 Federal Bldg. , Idaho Falls, Idaho; 468 New Customhouse, Denver, Colo.; 504 Federal Bldg. , Salt Lake City, Utah; 807 Post Office and Courthouse Bldg. , Los Angeles, and 724 Appraisers Bldg., San Franciscc, Calif. ; and also in the State Reclamation Engineer Office, State House, Boise, Idaho.
289. Smith, J. H., Geologic investigation of the Rome Point area, Wickford quadrangle, R. I.: 5 p., 1 pl. Sept. 30,1954 . Room 1, 270 Dartmouth St., Boston, Mass. ; Massachusetts Department of Public Works, 100 Nashua St. , Boston, Mass.

290. Smith, J. H., Geology of the proposed highway from Kitts Corner, West Greenwich, to a few hundred feet north of Bartons Corner, West Warwick, R. I.: 6 p., 1 map. Nov. 8, 1954. Rhode Island Development Council, State House, Providence, R. I.

291. Spicer, H. C., and Edwards, G. J., A resistivity survey to locate an aquifer in the glacial deposits near Marshfield, Wis.: 77 p. Oct. 7, 1954. Science Hall, University of Wisconsin, Madison, Wis.; Wisconsin Geological and Natural History Survey, Science Hall, University of Wisconsin, Madison, Wis.

292. Stefansson, K., Stratigraphy and structure of the area of the Ipnavik River, Alaska: 7 p., 2 figs., 1 pl. May 10, 1954. 2542 Dept. of Interior Bldg Washington, D. C.; Office of the Inspector, Naral Petroleum.Reserve No. 4, Fairbanks, Alaska.

293. Stefansson, K., and Mangus, M. D., Stratigraphy and structure of the area of the Avalik and Ketik Rivers, Alaska, 1949: 4 p., 1 pl. May 10, 1954. 2542 Dept. of Interior Bldg. , Washington, D. C. ; Office of the Inspector, Naval Petroleum Reserve No. 4, Fairbanks, Alaska.

294. Stefansson, K., and Thurrell, R. F., Jr., Stratigraphy and structure of the Wolf Creek anticline, Alaska, 1948: 3 p., 1 pl. May 10, 1954. 2542 Dept. of Interior Bldg., Washington, D. C.; Office of the Inspector, Naval Petroleum Reserve No. 4, Fairbanks, Alaska.

295. Stefansson, K., and Whittington, C. I., Stratigraphy and structure of the Umiat anticline: 11 p., 4 pls. May 10, 1954. 2542 Dept. of Interior Bldg., Washington, D. C.; Office of the Inspector, Naval Petroleum Reserve No. 4, Fairbanks, Alaska.

296. Stefansson, K., Thurrell, R. F., Jr., and Zumberge, J. H., Stratigraphy and structure of the area of the Colville River north of Umiat, Alaska, 1948: 29 p., 3 pls. May 10, 1954. 2542 Dept. of Interior Bldg., Washington, D. C. ; Office of the Inspector, Naval Petroleum Reserve No. 4, Fairbanks, Alaska.

297. Stramel, G. J., Map of the Wichita well-field area showing lines of equal changes in water level from August 30, 1940 to October 1, 1954: December 27, 1954. University of Kansas, Lawrence, Kans.; 1242-G General Services Administration Bldg., Washington, D. C.

298. Stringfield, V. T., and DeBuchananne, G. D., Modification of explanation of map of groundwater provinces in the United States, to show occurrence of saline water: 5 p. August 5, 1954. 1242-G General Services Administration Bldg., Washington, D. C. 
299. Stuart, W. F., Progress report on ground-water conditions at the Cayia mine near Crystal Falls, Mich.: 23 p., 10 figs. February 23, 1954. 4 Post Office Bldg., Ishpeming, Mich.; 1242-G General Services Administration Bldg., Washington, D. C.

300. Stugard, Frederick, Jr., Physical exploration for uranium during 1951 in the Silver Reef district, Washington County, Utah: 57 p., 13 figs., 7 tables. Jan. 11, 1954. 504 Federal Bldg., Salt Lake City, Utah; 468 New Customhouse, Denver, Colo.

301. Swain, F. M., Ostracoda from well, shot hole, and outcrop samples in Naval Petroleum Reserve No. 4, 1949: 75 p., 2 figs. May 10, 1954. 2542 Dept. of Interior Bldg., Washington, D. C.; Office of the Inspector, Naval Petroleum Reserve No. 4, Fairbanks, Alaska.

302. Swenson, F. A., Ground-water resources of Montana: 9 p., 1 fig. December 27, 1954. 318 Post Office Bldg. , Billings, Mont.; 510 Rudge-Guenzel Bldg., Lincoln, Nebr.; 1242-G General Services Administration Bldg., Washington, D. C.

303. Swenson, F. A., Water supplies from wells: 16 p. February 23, 1954. 510 Rudge-Guenzel Bldg. , Lincoln, Nebr.; 318 Post Office Bldg. , Billings, Mont.; 1242-G General Services Administration Bldg., Washington, D. C.

304. Swenson, H. A., The quality and character of Northwest waters: 17 p., 5 tables. April 19, 1954. P. O. Box 3418, Portland, Oreg.

305. Tailleur, I. L., and Kent, B. H., Progress report on the Kiligwa anticlinorium, 1953: 16 p., 1 fig., $1 \mathrm{pl}$. May 10, 1954. 2542 Dept. of Interior Bldg., Washington, D. C. ; Office of the Inspector, Naval Petroleum Reserve No. 4, Fairbanks, Alaska.

306. Tailleur, I. L., and Kent, B. H., Stratigraphy and structure of the Southern Foothills section between the Etivluk and Kiligwa Rivers, Alaska, 1951: 26 p., 2 figs., 4 pls. May 10, 1954. 2542 Dept. of Interior Bldg., Washington, D. C.; Office of the Inspector, Naval Petroleum Reserve No. 4, Fairbanks, Alaska.

307. Tailleur, Irvin L., Kent, B. H., and Reiser, H. N., Preliminary report on the stratigraphy and structure of the Kiligwa River area, Alaska, 1951: 18 p., 1 fig., 2 pls. May 10, 1954. 2542 Dept. of Interior Bldg., Washington, D. C. ; Office of the Inspector, Naval Petroleum Reserve No. 4, Fairbanks, Alaska.

308. Theis, C. V., Computation of drawdown at equilibrium caused by wells drawing water from an aquifer fed by a finite straight-line source: 6 p., 2 figs. November 10, 1954. 1242-G General Services Administration Bldg. , Washington, D. C.

309. Theis, C. V., and Brown, R. H., Drawdown in wells responding to cyclic pumping: 14 p., 3 figs. November 10, 1954. 1242-G General Services Administration Bldg., Washington, D. C.
310. Theis, C. V., and others., Estimatingtransmissibility from specific capacity: 11 p., 2 figs. November 10, 1954. 1242-G General Services Administration Bldg., Washington, D. C.

311. Thompson, M. L., Progress report, records of sediment discharge of the Mississippi River, St. Louis, Mo., Oct. 1950-Sept. 1952: 13p., 4 figs., 10 tables. March 26, 1954. 1004 New Federal Bldg., St. Louis, Mo.; 510 Rudge-Guenzel Bldg., Lincoln, Nebr.; 1242-L General Services Administration Bldg., Washington, D. C.

312. Thompson, R. M., and Barksdale, W. L., Stratigraphy and structure of the area of the Utukok River with notes on the Corwin-Cape Beaufort region, Alaska, 1948: 40 p., 3 pls. May, 10, 1954. 2542 Dept. of Interior Bldg., Washington, D. C.; Office of the Inspector, Naval Petroleum Reserve No. 4, Fairbanks, Alaska.

313. Thurrell, R. F., Jr., Preliminary report on the stratigraphy and structure of the area of the Colville River from Ipnavik to Kurupa Rivers, Alaska, 1947: 9 p., 2 pls. 2542Dept. of Interior Bldg., Washington, D. C.; Office of the Inspector, Naval Petroleum Reserve No. 4, Fairbanks, Alaska.

314. Tice, R. H., Magnitude and frequency of floods in the Shenandoah Valley of Virginia: $32 \mathrm{p}$., 14 figs., 1 map. October 1, 1954. Natural Resources Bldg., Charlottesville, Va.

315. Trainer, F. W., Geology and ground-water resources of the Matanuska Valley agricultural area, Alaska: 134 p., 4 pls., 24 figs. March 31, 1954. 210 Glover Bldg., 5th and E Sts., Anchorage, Alaska; 206-A Glover Bldg. , 5th and E Sts., Anchorage Alaska; Wright Bldg., Palmer, Alaska; 1242-G General Services Administration Bldg., Washington, D. C.

316. Trimble, D. E., An account of the geology of Oregon City, Oreg., with notes on adjacent West Linn and Willamette, Oreg.: 8 p., 1 map. June 1, 1954. 468 New Customhouse, Denver, Colo.; Office of the Director, State Department of Geology and Mineral Industries, 1069 State Office Bldg., Portland, Oreg.; Office of the City Engineer, City Hall, Oregon City, Oreg.

317. Troyer, M. L., McKay, E. J., Wallace, S. R., and Soister, P. E., Geologic map of the east-central part of the Pumpkin Buttes area, Campbell County, Wyo.: 1 map. Aug. 20, 1954. Room 724, Appraisers Bldg., San Francisco, Calif.; 468 New Customhouse, Denver, Colo.; Geology Hall, University of Wyoming, Laramie, Wyo.; 807 Post Office and Courthouse Bldg., Los Angeles, Calif.; 1214 Big Horn Ave., Worland, Wyo.; 315 Federal Bldg., Billings, Mont.; Bureau of Mines, Rapid City, S. Dak.; the following offices of the U.S. Atomic Energy Commission: Denver Explorations Branch, Denver Federal Center, Denver, Colo.; Hot Springs Suboffice, Hot Springs, S. Dak.; Douglas Suboffice, Douglas, Wyo. 
318. Tuttle, C. R., Geologic interpretation of seismic data for relocation of Route 2 in Athol, Mass., cut, stations 215-245: 2 p. , 5 pls. July 27, 1954. Room 1, 270 Dartmouth St., Boston, Mass.; Massachusetts Department of Public Works, 100 Nashua St., Boston, Mass.

319. Tuttle, C. R., Geologic interpretation of seismic data for relocation of Route 2, cut, stations 250-266 in Athol, Mass.: 2 p., 2 pls. July 27, 1954. Room 1, 270 Dartmouth St., Boston, Mass.;

Massachusetts Department of Public Works, 100 Nashua St. , Boston, Mass.

320. Tuttle, C. R., Geology and geologic interpretation of seismic data for relocation of Route 2 in Athol, Mass., cut, stations 112-138: 2 p., 2 pls. Sept. 30, 1954. Room 1, 270 Dartmouth St., Boston, Mass.; Massachusetts Department of Public Works, 100 Nashua St., Boston, Mass.

321. U. S. Geological Survey, Resources Group, Salt deposits of the United States, incomplete compilation from published sources, 1950: 2 p., 1 map. Jan. 11, 1954. Muskingum Conservancy Bldg., New Philadelphia, Ohio; Menlo Park, Calif.; State Geological Survey, University of Kansas, Lawrence, Kans.; Geological Survey Division, State Department of Conservation, Lansing, Mich.; State Geological and Natural History Survey, State Education Bldg., University of the State of New York, Albany, N. Y.

322. Visher, F. N., Rapp, J. R., Babcock, H. M., and Durum, W. H., Geology and groundwater resources of the North Platte. Irrigation Project area in Goshen County, Wyo.: 177 p., 5 pls., 12 figs. July 30, 1954. 300 Federal Recreation Bldg., Billings, Mont.; 1242-G General Services Administration Bldg., Washington, D. C.

323. Voegeli, P. T., and Crow, N. B., Logs of test holes and wells in the Central Snake River Plain, Idaho: 30 p., 1 fig. December 27, 1954. 720 Idaho St. Boise, Idaho; 1242-G General Services Administration Bldg., Washington, D. C.

324. Waite, H. A., Problems and control of leaking artesian wells: 13 p. July 23, 1954. 503-A Federal Bldg., Salt Lake City, Utah; 1242-G General Services Administration Bldg., Washington, D. C.

325. Waite, H. A., and others, Inventory of ground-water pumpage in three irrigation districts in southern Utah, 1953: 9 p., 11 figs. July 23, 1954. 503-A Federal Bldg., Salt Lake City, Utah; 1242-G General Services Administration Bldg., Washington, D. C.
326. Wallace, S. R., Olson, J. C., and Roadifer, J. E., Geologic map and cross sections of the Little Johnnie thorium deposit, Gunnison County, Colo.: 1 map, cross sections. July 19, 1954. Grand Junction, Colo.; 468 New Customhouse, Denver, Colo.; 504 Federal Bldg. , Salt Lake City, Utah.

327. Walton, M. S., Jr., Rossman, D. L., Hill, M. E. and Balsey, J. R., Jr., Magnetic survey of part of Naval Petroleum Reserve No. 4 by airborne magnetometer: 26 p., 4 pls. May 10, 1954. 2542 Dept. of Interior Bldg., Washington, D. C.; Office of the Inspector, Naval Petroleum Reserve No. 4, Fairbanks, Alaska.

328. Washburn, R. L., Preliminary investigation of ground water in the East Sound area, Orcas Island, San Juan County, Wash.: 26 p. , 2 pls. June 17, 1954. 2128 South 38th St., Tacoma, Wash.; 1242-G General Services Administration Bldg., Washington, D. C.

329. Webber, E. J., Stratigraphy and structure of the area of the Meade and Kuk Rivers and Point Barrow: 13 p., 1 fig., 2 pls. May 10, 1954. 2542 Dept. of Interior Bldg., Washington, D. C.; Office of the Inspector, Naval Petroleum Reserve No. 4, Fairbanks, Alaska.

330. Webber, E. J., Stratigraphy and structure of the area of the Titaluk River and upper part of Ikpikpuk River, Alaska, 1948: 4 p., 1 pl. May 10, 1954. 2542 Dept. of Interior Bldg. , Washington, D. C.; Office of the Inspector, Naval Petroleum Reserve No. 4, Fairbanks, Alaska.

331. Webber, E. J., and Detterman, R. L., Preliminary report on the stratigraphy and stmucture of the area of the Nanushuk River, Alaska, 1947: 7 p., 2 pls. May 10, 1954. 2542 Dept. of Interior Bldg., Washington, D. C.; Office of the Inspector, Naval Petroleum Reserve No. 4, Fairbanks, Alaska.

332. Whittington, C. L., and Keller, A. S., Stratigraphy and structure of the area of the Upper Meade River, Alaska, 1950: 8 p., 3 pls. May 10, 1954. 2542 Dept. of Interior Bldg. , Washington, D. C.; Office of the Inspector, Naval Petroleum Reserve No. 4, Fairbanks, Alaska.

333. Whittington, C. L., and Sable, E. G., Preliminary geologic report of Sadlerochit River area, 1948: 18 p., 1 pl. May 10, 1954. 2542 Dept. of Interior Bldg., Washington, D. C. ; Office of the Inspector, Naval Petroleum Reserve No. 4, Fairbanks, Alaska.

334. Whittington, C. L., and Stevens, J. M., Stratigraphy and structure of part of the Carbon Creek and Ketik anticlines, Alaska, 1951: 13 p., 1 fig., 3 pls. May 10, 1954. 2542 Dept. of Interior Bldg., Washington, D. C.; Office of the Inspector, Naval Petroleum Reserve No. 4, Fairbanks, Alaska. 
335. Whittington, C. L., and Troyer, M, L., Stratigraphy and structure of the area of the Kigalik and Awuna Rivers, Alaska, 1948: 7 p.; 2 pls. May 10, 1954. 2542 Dept. of Interior Bldg. , Washington, D. C. ; Office of the Inspector, Naval Petroleum Reserve No. 4, Fairbanks, Alaska.

336. Wilson, H. D., Jr., Water levels in observation wells in Santa Barbara County, Calif., in 1953: 19 p., 9 pls. September 15, 1954. 221 Redondo Ave., Long Beach, Calif.; 2520 Marconi Ave.; Sacramento, Calif.; 836 Anacapa St., Santa Barbara, Calif.; 1242-G General Services Administration Bldg., Washington, D. C.
337. Wood, G. H., Jr., Johnson, R. B., and Dixon, G. H., Geology and coal resources of the Gulnare, Cuchara Pass, and Stonewall area, Huerfano and Las Animas Counties, Colo.: 46 p., 11 map items. July 22, 1954. 468 New Customhouse, Denver, Colo.; 504 Federal Bldg., Salt Lake City, Utah.

338. Yuster, S. T., Core analysis of selected samples from 1949 wells in Naval Petroleum Reserve No. 4, 1950: 2 p., 3 figs. May 10, 1954. 2542 Dept. of Interior Bldg., Washington, D. C.; Office of the Inspector, Naval Petroleum Reserve No. 4, Fairbanks, Alaska. 
Agriculture Engineering: Curriculums---- 53 Alaska:

Anticlines, Carbon Creek and Awuna----- 83 Discovery, structure-_._._._- 186 The Driftwood-_._._. 84 Driftwood, new interpretation--------- 260 Evaluation, as related to petroleum exploration-_-_-_-_-_-_-- 94

Barroe, Cape Simpson, and Umiat areas,

heavy minerals, analysis-.---_--.--- 215

Brooks Range, Lisburne limestone-.-.-.- 38

Cape Simpson, test pit operations, geological results-_-_._-_-_-_-_--- 226

Colville River area, geologic structures-_-_._._..... 85

Duke Island, geologic map-_.......- 150 Gravity anomaly-..-_-_..- 63 Heavy minerals, studies, northern Alaska-.._-_._._...-.- I62, 216 Zonation, Tertiary and Cretaceous rocks, central northern Alaska-.-.-.- 161 Index, publications-_- 6 Iniskin Peninsula, geologic map, structure sections-_._-_._-_._- 118

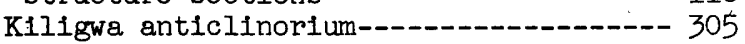

Kongakut-Firth Rivers area, geology, regional interpretation--.....- 181

Kuparuk River area, lower, reconnaissance survey-_-_-_-_-_----- 106

Kuskokwin area, geologic map-..-.-.-.-- 126

Lisburne limestone, petrology-..--- 104, 159 Porosity and petrology, Kanayut, Nanushuk and Itkillik Lakes area----- 160

Macrofossils, taxonomic and

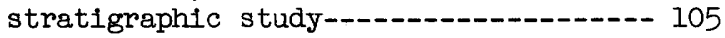

Malaspina district, reconnaissance

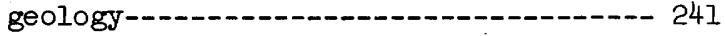

Maps, aeromagnetic, Southern Prince of Wales Island-_-_-_-_-_-_ 97 Geologic, Mt. McKinley quadrangle----- 251 Gubik anticline, structure contour---- 9 Photogeologic, Naval Petroleum

Reserve No. 4_...

Matanuska Valley, agriculture area, geology and ground-water resources----- 315

Maybe Creek area, anticlines, photogeologic evaluation--.-.-.--.----- 87

Microfossil investigations, progress report-_._- 169 Summary, Apr11 1948-49-..-.-_-_-- 172 Micropaleontological studies---.------ 19

Mineral studies, significance and results-_-_-_-_-_-_-_-_-_-_-_-_-- 79

Mississippian rocks, Kanayut, Nanushuk, and Itililk Lakes area-_-_-_-_-_--:- 25

Naval Petroleum Reserve No. 4,

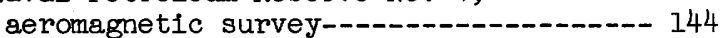
Base of tertiary, seismic evidence--- 65 Core analysis, 1949 wells-_._._-_.-. 338 Facies patterns, revisions--.----.---- 231 Formation of reservoirs-_._._._._.-. 155 Geophysical and geological data---.-- 64
Alaska-Continued

Naval Petroleum Reserve No. 4-Continued

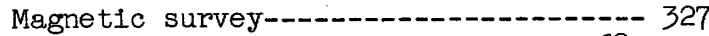
Microfossil investigations-...--- 168, 170 Ostracoda-.....-.-. 301

Paleontologic correlations-_-_-_-..-- 20

Paleontologic studies-.-.-.-.----- 21

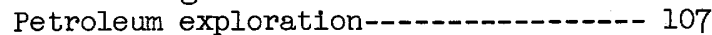

Revisions and correlations based

on Foraminifera-......-. 171

Sandstone cores, Tertiary and

Cretaceous-_..-_._-_._- 153

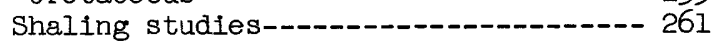

Subsurface stratigraphy-----_----- 233

Okokmilage and John Rivers area,

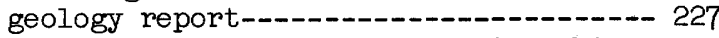

Petroleum possibilities, stratigraphic

units, northern Alaska-.--_-_-_---- 230

Photogeologic mapping-_-_._...-... 86

Photogeology studies, Chandler River

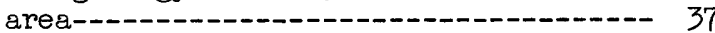

Porosity and permeability,

summary of data--_-_-_- 151

Power sites, geologic investigations,

Cooper, Grant, Ptarmigan, and

Cresent Lakes--.-- 240

Sadlerochit River area, geology---.---- 333

Sagavanirtok River area, geology-------- 108

Sand formation, analysis, deformed

geosyncline, northern Alaska-.-.-.-.--- 152

Sedimentation analysis, drilling

developments and geologic field work--- 232

Seldovia River area, water-power

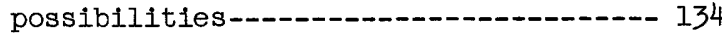

Selected anticlines, photogeologic

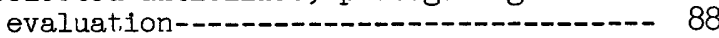

Simpson area, stratigraphy and

paleontology--.---.---- 245

Simpson Seeps region, correlation------- 258

Stratigraphy and structure,

anticlines, Aupuk---_-_-- 74

Stratigraphy and structure,

anticlines, Big Bend-_-_-_-_-_- 70

Carbon Creek and Ketik-_-_._._.-.-- 334

Driftwood-..-.-.-.-.-- 263

Grandstand and Hawk-_-_-_-_.-.- 69

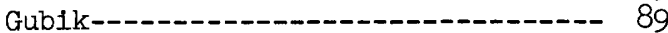

Titaluk-......... 36

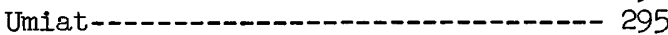

Wolf Creek-_-_-_-_-_- 294

Avalik and Ketik Rivers area-.-.-.--- 293

Canning and Shaviovik Rivers area-.-.- 143 Colville River area-_-_-_-_-_---- 71, 296

Colville River from Ipnavik to

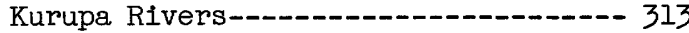

Colville River, south of---_--_----- 109

Driftwood-Noluk area--_--_-_-_-_----- 262

Eastern Brooks Range-_-_.....-- 35

Etivluk and Kuna Rivers area---------- 182

Etivluk River to Kiligwa River area--- 306

Ipnavik River area--_-_-_-_-_-_-_---- 292

Kigalik and Awuna Rivers area--------- 335 
Alaska-Continued

Stratigraphy and structure-Continued

Kiligwa River area----_-_-_-_-_----- 307

Killik, Chandler, Anaktuvuk, and

Colvilie Rivers area--_-_-_-_------ 234

Kokilik and Kukpowruk Rivers area-.--- 49

Kurupa, Oolamnagavik, Killik, and

Colville Rivers area-..-........-. 50

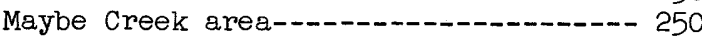

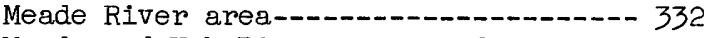

Meade and Kuk Rivers area and

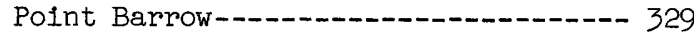

Nanushuk River area-_-_._._._._._. 331

Noatak district_-_._._._. 72

Okpikruak and Kiruktagiak

Rivers area-..-_..._-_._- 229

Oolamnagavik, Kurupa, and

Etivluk Rivers area-_._-_._._.-. 48

Shadlovik and Canning Rivers area---.- 110

Shaviovik and upper Sagavanirtok

Rivers area--_-_-_-_-_-_-_-- 142

S1ksikpuk-Nanushuk Rivers area------- 228

Simpson area, subsurface---_-_-_-_---- 257

Titaluk and upper Ikpikpuk Rivers

area--_-_-_-_-_-_- 330

Utukok River area and Corwin-

Cape Beaufort region--.---_-_--- 312

Utukok-Kokolik Rivers area--.--.----- 264

Structural patterns, Seward B 2

quadrangle-_... 58

Susitna and Maclaren Rivers area, high-

way construction, geologic factor\$----- 137

Tuxedni Bay, magnetic deposits-.-.-..-- 103

Umiat area, petroleum possibilities-.-.- 141

Wells, logs, Gubik test well 1-......- 2

Gubik test well 2--... 3

Umiat test well 8-_... 4

Umiat test well Il-_..... 5

Natural gas analyses, Gubik test

well 1, Umiat test well 8.......- I

Paleontology-..-...-. 22

Simpson test 1 , core analyses report-- 235

South Barrow, test, correlation-.-.-- 163

South Barrow test 1, core analysis---- 236

South Barrow test 1 , report on

three specimens-1- 156

South Barrow test 2, core analysis---- 237

South Barrow test 1 and 2, petrology

and reservoir properties-_-_-_-_- 154

Umiat test, subsurface structure-..-- 10

Umiat test 1 , reservoir

characteristic's-_-_-_-_._-_- 157

Umiat test 9, petrography and

reservoir characteristics-_._-_-_- 158

Arizona:

Ground water, G1la River-_-_-_-n 114

Papago Indian Reservation-..-_-...-. 51

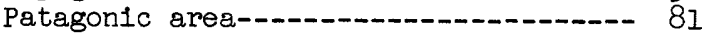

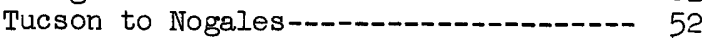

Yuma County-_-_-_-_-_-_-_-_-_-- 135

Lake Mead, sedimentation-_-_._._...- 101

Maps, geologic, Navajo and Hopi

Indian Reservations-_-_..-_-_-_- 116

Mineral resources, San Carlos Indian

Reservation--.---_-_-

Patagonic area, geology-n-

Building stones:

Natural and artificial, resistance to water and frost
California:

Sacramento Valley, water, interchange

of surface and ground--.--_-_-_--. 59

San Bernardino area, hydrologic and

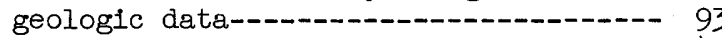

San Diero County, water wells-.......- 43

San Francisco area, map, bedrock-

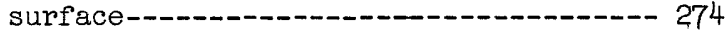

San Joaquin Valley, ground water,

estimated storage--_-_- 66

Santa Barbara County, observation

wells, water levels-_--_-- 336

Shasta copper-zinc district, map,

geologic-_-_- 148

Water Bulletin, Southern

California, 1953-_-_...-. 127

Water flow, Agua Caliente Spring---.--- 246

Water-bearing deposits, estimates of

permeability-_.- 44

Clays:

Physico-chemical structure--D------- 28

Swelling and composition--n-_-n 91

Colorado:

Drill-hole logs, Blue Mesa County------- 213

Huerfano and Las Animas Counties,

coal resources and geology-_--_------ 337

Maps, geologic, Eureka Gulch area,

Gilpin County-........ 286

Gilpin and Clear Creek Counties-..-.-- 285

Little Jonnie thorium deposit------ 326

Photogeologic, Orange Cliff 6

quadrangle -

Routt and Moffat Counties, mineral

fuels and geology-_._. 15

Towaoc, ground water-an- 249

Connecticut:

Ground water, conditions, Haddam Conn--- 61

Investigations, year ending

June 30, 1954_... 61

Cuba:

Iron deposits-- 73

Curriculums:

Agriculture engineering--_-_-_---- 53

Delaware:

Ground water, 1952 Ievels-_-_-_- 183

Earth pressure:

Measurement, "flat jack test"-...-...-- 31

Iron-ore mines of eastern France-..-.- 30

Engineering geology:

Geophysical road surveys-_-_-_-_.-. 76 ,

$117,119,189,190,191$,

$192,193,194,195,196$,

197, 198, 199, 289, 318,

319,320

Florida:

Drilling, radioactivity anomalies------- 47

Lee County, surface waters, quality--.-- 39

Santa Rosa County, ground water,

studies-.-.-.-. 120

Stratigraphy, outcropping formations,

Southern Florida-_-_-_-_._-_-_- 275

Taylor County, pumping test, results---- 68

Water supply--.-.- 40

Georgia:

Drilling, radioactivity

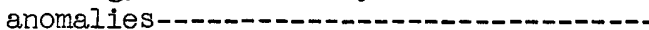


Idaho:

Bingham and Power Counties,

well records-_-_-_-_- 288

Cassia County, ground water,

resources-_-__-____-__-_- 219

Well records-_-_-_-_-_-_ 217

Central Snake River Plain, logs, test

holes and wells--

Clay deposits, Bovill, Latah County--.-- 267 Camas Prairle, Lewis and Idaho

Counties--.-- 269

High-alumina, Canfield-Rogers,

Latah County-_.- 268

High-alumina, Latah County-.....- 270

Olsen high-alumine and high-iron,

Latah County-..--..- 272

Stanford, Latah County--.-_-_-_-_- 273

Stockton and Stanley H1ll,

Kootena1 County-_._.-.- 266

Ground water, development and problems-- 60

Shoshone County, geologic map,

Wallace quadrangle-......- 26

Igneous rocks:

Chemical analysis-_- 129

Iowe:

Drilling data, recent, Dubuque County--- 90

Dubuque County, map, geologic-....... 90

Iron deposits:

North Amer1ca, Cuba, and Puerto R1co-..- 73

Iron mines:

Eastern France, measurement of

earth pressure-1.-

\section{Kansas:}

Ground water, date, M1ssourl River

Basin units, 1952, 1953-....... 188, 187

Map, W1chtta well-fleld, water level-... 297

Lands I1des:

Sainte-Adresse Cliff

Loulsiana:

Ground-water conditions,

Camp Cla1borne-. 180

Camps Livingston and Beauregard and

Esler Fleld-_. 179

Ground-water recharge, southwestern

Loulsiana-.-_-_._-_- 78

Maps, water-level contour, analysis,

southwestern Loulsiana._._._._-_-- 77

Vermillion River basin, surface-water

supplies-_._..._...- 115

Maine:

Maps, aeromagnetic, Franklin and

Somerset Counties-_-_-_-_-_-_-_.--- 96

Sagadahoc Bay, current velocities--.---- 149

Maryland:

Graphs, sediments, water-bearing

formations, southern Maryland-_-_------ 224

Maps, Miocene and Cretaceous,

southern Maryland-_-_-_-_-_-_-_-_--- 224

Salinity studies, Eastern Shore

estuaries-_..- 218

Massachusetts:

Geophysical road surveys-_..- 76 , $117,119,189,190,191$, 192, 193, 194, 195, 196, $197,198,199,289,318$, 319,320
Metamorphism:

Regional, observation

of a front-_- 32

Michigan:

Crystal Falls, ground water,

Cayia mine--

Saginaw lowland, geomorphology,

pre-Pleis tocene--_-_-_- 255

Minnesota:

Maps, aeromagnetic-_-_-_- 200 , $201,202,203,204,205,206,207,208$

M1ssissippi:

Tylertown, flood of August 1953--.-.-.- 11

Missouri:

M1ssissipp1 River, sediment discharge--- 311

Spring River basin, low-water study-..-- 24

Montane:

Ground water, resources-n-_-n- 302

Johnnie Gulch quadrangle, geology-...-- 92

Map, geologic, Boxelder quadrangle-..-- 167 Chelsea and Poplar quadrangles-...-.- 54 Portage quadrangle-.-...- 166 Uranium-bearing materlal and anoma-

lous radioactivity, distribution, Jefferson City quadrangle......... 214

St1llwater County, geologic maps

and sections-...

Nebraska:

Observetion wells, water levels, prior to January 1, $1954 \ldots$

Nevada:

Elko County, geologic map-_-_-_-_-- 102

Humboldt County, equifers-_.........- 173

Lake Mead, sedimentation-............. 101

New Jersey:

Observation wells, unreliable types--.-- 254

Seabrook, hydrologic studies-_....... 253

New Mexico:

Map, aeromagnetic, part of Grant

County--_-_.-.- 67

Geologic, Black Hawk mining district-- 100 Geologic, White Signal district,

Grant County-.-_-_.-.- 99

Mora County, Coyote mining district, copper and uranium-_._.-.- 164

New York:

Franklin County, pre-Cambrian geology,

Chateaugay quadrangle-...- 220

Maps, geologic, Big Moose and

Port Leyden quadrangles-_..._._.-.-.- 41

Loon Lake quadrangle-_-_-_-_-_- 247

St. Lawrence County-_-_-_-_-_ 42

Nassau County, water level data--.----- 98

Public water supply, average daily,

Kings, Queens, and Nassau Counties,

L. I., 1904 through 1953-_._._._- 175

Salt-water encroachment, studies,

Long Island-_...- 176

Suffolk County, streamflow-_-_-_-_-.-- 265

North America:

Iron deposits-_-_-_- 73

North Carolina:

Kings Mountain district,

metamorphic rocks-5-_-_-_-_-_-_--- 248

Map, geologic, Morgantown quadrangle---- 140

North Dakota:

Devils Lake region,

late Pleistocene- 
Oregon:

Gaging stations, operation 1950-1953---- 239

Oregon City area, geology-..-...- 316

Puerto Rico:

Iron deposits-_-_-

Radon:

Behavior and control,

in mountain streams

Rhode Island:

Geology, proposed highway, Kitts

Corner to Bartons Corner---.--- 290

Salt:

Deposits of the United States-_-_-_-- 321

Sand:

Arkos:c, fusion by intrusive andesite--- 14

South Carolina:

Drilling, radioactivity anomalies---.--- 47

Kirgs Mountain district,

metamorphic rocks-_-_-_-_- 248

South Dakota:

Penningtc:. County, geology,

Eureka pegmatite-_-_-_-_-_-_-- 256

Yankton area, geology-_._._._.-. 284

Stratigraphic sections:

Phosphoria formation, measured

and sampled 1953

Tennessee:

Heavy minerals, western Tennessee-...-- 23

Texas:

Devils and Pecos River basins,

floods, June 27, 28, $1954 \ldots$

Scurry and Borden Counties,

flood, Apri1 12, 13, 1954-

Water diversions, Red River to Lake

Dallas, February and March 1954-.--.--- 128

Titanium:

Field method for determination---.----- 283

World resources-_._._.-. 165

Uranium:

Physical exploration,

Washington County, Utah-..-- 300

Utah:

Artesian wells, problems

and leakage control---

Grand County, Shinarump 1

uranium mine, geology-.-.--_-.-.-.- 82

Ground-water pumpage, southern Utah--.-- 325

Maps, geologic, La Sal Mountains--.---- 132

Geophysical, Salt Lake Valley-------- 95

Photogeologic, Emery County,

Castle Dale 16 quadrangle-..-.-.-- 278

Desert Lake 6 quadrangle-..-.-.---- 210

Desert Lake 7 quadrangle--.---.--- 55

Desert Lake 8 quadrangle-_..-_.-- 221

Desert Lake 9 quadrangle-.-...--.- 46

Desert Lake 10 quadrangle-.--.---- 56

Desert Lake 12 quadrangle--.------ 211

Desert Lake 15 quadrangle-.---.--- 123

Desert Lake 16 quadrangle-------- 185

Stinking Spring Creek

1 quadrangle
Utah-Continued

Maps, geologic-Continued

Photogeologic-Continued

Stinking Spring Creek 10

quadrangle--_-_-- 122

Tidwell 6 quadrangle-.......... 18

Tidwell 12 quadrangle-_-_-_------ 212

Woodside 5 quadrangle-_-_-_-..--- 222

Woodside 12 quadrangle--.-_-_---- 223

Emery and Carbon Counties,

Desert Lake 1 quadrangle--.------ 279

Desert Lake 2 quadrangle-_._.-.- 209

Woodside 4 quadrangle-_-.-_-_--- 131

Garfield County, Kaiparowits

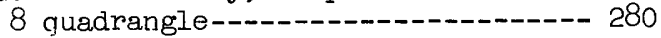

Garfield and Kane Counties, Circle

Cliffs 13 quadrangle------------- 145

Garfield and San Juan Counties,

Orange Cliffs 15 quadrangle-.---.- 147

Orange Cliffs 16 quadrangle--.---- 244

Garfield and Wayne Counties,

Orange Cliffs 9 quadrangle-.-.--- 57

Grend and Emery Counties,

Moab 13 quadrangle----------n--- 75

Kane County, Straight Cliffs

2 quadrangle-_._-_-_-_- 282

Straight Cliffs 7 quadrangle------ 146

Straight Cliffs 9 quadrangle------ 252

Kane and San Juan Counties, Navajo

Mountain 5 quadrangle-_.....--- 16

Navajo Mountain 12 quadrangle----- 17

San Juan County, Bluff

3 quadrangle-_..... 184

Carlisle 2 quadrangle----_------- 276

Carlisle 7 quadrarigle--.---_------ 130

Carlisle 10 quadrangle-.-.------- 277

Carlisle 11 quadrangle-.......-- 242

Carlisle 14 quadrangle-.....-.--- 111

Carlisle 15 quadrangle-..-.------ 112

Elk Ridge 2 quadrangle--.--_----- 113

San Juan and Garfield Counties,

Carlisle 13 quadrangle-_.-.-.---- 243

Marysville, alunitic alteration-------- 225

Washington County, uranium,

physical exploration---_- 300

Virginia:

Eastern Shore Peninsula, geology

and ground water-..-- 287

Shenandoah Valley, floods,

magnitude and frequency-_-_-_-_---- 314

Washington:

Clay deposits, high-alumina, Spokane---- 271

Ferry County Highway, landslide

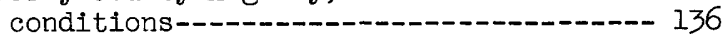

Olympic Peninsula, aeromagnetic map----- 125

San Juan County, ground water--.---.-- 328

Water:

Chemical quality, in tidal rivers------ 139

Computation of drawdown

at equilibrium--_-_-_- 308

Drawdown in wells, responding

to cyclic pumping-_-_-_-_- 309

Industrial supply, United States--.---- 174

Northwestern United States, quality-.-- 304 


\section{Water-Continued}

Primary, availability---_--_-_-_---- 178

Saline, map showing occurrence--.-.---- 298

Transmissibility, estimation

by "Slug test"-._-_-_.-_ 80

Estimation from specific gravity----- 310

Well supplies--.-. 303

Wisconsin:

Aquifer, location survey, near

Marshfield
Wyoming:

Goshen County, North Platte

Irrigation Project area, geology

and ground-water resources-_._-_.-_- 322

Ground water, Edgerton vicinity---.--- 13

Map, geologic, Campbell County,

Pumpkin Buttes area---.-- 317

Photomosaic, radioactivity

anomalies, Carbon and

Sweetwater Counties-_-_._-_-_-_- 124 


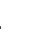

